\title{
Waste Isolation Facility Description for the Spent Fuel Cycle Bedded Salt May 1977
}

This report was prepared by Parsons Brinckerhoff Quade \& Douglas, Inc. under subcontract $86 \mathrm{Y}-16543 \mathrm{~V}$ with Union Carbide Corporation, Nuclear Division, under contract number W-7405eng-26 with the Energy Research and Development Administration. The subcontract was administered by the Office of Waste Isolation.

This informal document contains information which is preliminary and may be fragmentary or of limited scope. The assumptions, views, and conclusions expressed in this document are those of the author and are not necessarily to be interpreted as those of Union Carbide Corporation, Nuclear Division, or USERDA.
NOTICE an account of work This report was prepared ates Government. Neither sponsored by the United the United States Energy Research and Development Administration, nor any or their employees, nor any employees, makes any subcontractors, or ther implied, or assumes any legal warranty, expressibility for the accuracy, completeness liabily iness of any information, apparatus, product or process disclosed, or represents infringe privately owned rights. 


\section{DISCLAIMER}

This report was prepared as an account of work sponsored by an agency of the United States Government. Neither the United States Government nor any agency Thereof, nor any of their employees, makes any warranty, express or implied, or assumes any legal liability or responsibility for the accuracy, completeness, or usefulness of any information, apparatus, product, or process disclosed, or represents that its use would not infringe privately owned rights. Reference herein to any specific commercial product, process, or service by trade name, trademark, manufacturer, or otherwise does not necessarily constitute or imply its endorsement, recommendation, or favoring by the United States Government or any agency thereof. The views and opinions of authors expressed herein do not necessarily state or reflect those of the United States Government or any agency thereof. 


\section{DISCLAIMER}

Portions of this document may be illegible in electronic image products. Images are produced from the best available original document. 


\section{Waste Isolation} Facility Description for the Spent Fuel Cycle Bedded Salt May 1977

This report was prepared by Parsons Brinckerhoff Quade \& Douglas, Inc. under subcontract 86Y-16543V with Union Carbide Corporation, Nuclear Division, under contract number W-7405eng-26 with the Energy Research and Development Administration. The subcontract was administered by the Office of Waste Isolation.

This informal document contains information which is preliminary and may be fragmentary or of limited scope. The assumptions, views, and conclusions expressed in this document are those of the author and are not necessarily to be interpreted as those of Union Carbide Corporation, Nuclear Division, or USERDA.

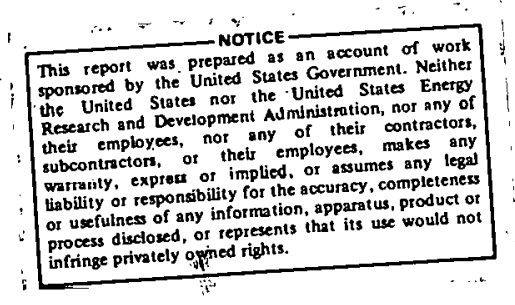

Parsons Brinckerhoff Quade \& Douglas, Inc.

UISTRIBUTION OF THIS DOCUMENT IS UNLIMITEQ 
Table of Contents

Page

1.0 REFERENCE CONCEPT 1

1.1 Introduction 1

1.2 Design Assumptions $\quad$ : 2

1.3 Criteria for Receiving Canistered Waste . . 3

1.4 Criteria for Receiving Low-Level Waste 3

2.0 WASTE HANDLING OPERATIONS 4

2.1 Handling Operations for Canistered Spent Fuel Assemblies 4

2.2 Low-Level Waste Handling Operations . 5

3.0 SURFACE FACILITIES 6

3.1 Canistered Waste Building 6

3.2 Low-Level Waste Building . 6

3.3 Support Buildings $\quad 6$

3.4 Excavated Salt Disposal

3.5 Railroad Yard $\quad 8$

4.0 SHAFTS AND HOISTS $\quad 8$

4.1 Canistered Waste Shaft $\quad 8$

4.2 Low-Level Waste shaft 9

4.3 Men and Material (M\&M) Shafts 9

4.4 Ventilation Exhaust Shaft 10

5.0 MINE FACILITIES 10

5.1 BWR Fuel Waste 10

5.2. PWR Fuel Waste 11

5.3 Low-Level Waste 11

5.4 Mining Operations 11

6.0 VENTILATION SYSTEMS 12

6.1 Subterranean Ventilation Systems $\quad 12$

6.2 Ventilation of Surface Structures 14 
$\begin{array}{lll}7.0 & \text { LAND IMPROVEMENTS } & 14\end{array}$

7.1 Site Clearing, Grading, and Landscaping $\quad 14$

7.2 Roads and Parking $\quad 14$

7.3 Railroad Access 115

7.4 Fencing 15

7.5 Storm Water Runoff

$\mathbf{8 . 0}$ UTILITIES

8.1 Domestic Water 15

8.2 Electric Power 15

8.3 Sanitary Waste Disposal 16

8.4 Fuel $\quad 16$

8.5 Steam 16

8.6 Communications 16

9.0 ACCIDENTS, CONFINEMENT AND SAFETY CRITERIA $\quad ; \quad 17$

9.1 Accident Situation 17

9.2 Confinement Systems 17

$\begin{array}{ll}9.3 \text { Monitoring } & 18\end{array}$

9.4 Onsite Radwaste Management $\quad 18$

9.5 Protection of Repository Personnel $\quad 19$

9.6 Protection of the Public 20

$\begin{array}{lll}9.7 & \text { Mine Safety } & 20\end{array}$

Appendix A Mine Layout and Development

Appendix B Mine Operations

Appendix C Shaft Construction Information

Appendix D Analysis Concerning Canister Rupture Inside the Proposed Waste Insolation Facility 


\section{DESCRIPTION OF WASTE ISOLATION FACILITIES}

\subsection{REFERENCE CONCEPT}

\section{$1.1 \quad$ Introduction}

A demonstration of the feasibility of using bedded salt as a repository for highly radioactive solid wastes was provided by Project Salt Vault. This pilot repository, in which irradiated reactor fuel elements were used to simulate the wastes, was operated in a completely retrievable manner from 1965 to 1968.

A typical Federal repository would consist of a large number of chambers excavated within a suitable geologic formation along with access shafts and various supportive surface structures. Wastes will be received by rail at the repository's surface facilities, the shipments of wastes arriving in specially designed containers and subsequently treated separately according to waste type. The waste containers would be inspected for damage that may have occurred during shipping, and remedial action will be taken if required. Finally, the containerized waste will be lowered into the repository and emplaced in the appropriate chamber.

Initially, the repository will be operated in a retrievable mode -- that is, all emplaced waste could be removed from the repository with relative ease should circumstances develop that require this action. After the repository has operated satisfactorily for a suitable length of time, operations performed to maintain retrievability will be terminated and storage rooms will be back-filled with some of the excavated rock material. Finally, when the repository is full, the surface facilities will be decommissioned and dismantled, and all shafts to the mine will be plugged and sealed.

All facilities in the repository will be carefully designed to protect the public and operating personnel from radiation and/or contamination hazards under both normal operating and emergency, or accident situations. The facilitles will also be designed to deal promptly and effectively with emergency or accident situations. In addition, surface facilities containing radioactive materials will be designed to maintain their integrity during natural disasters.

ERDA will acquire fee simple title to all the land area overlying the excavations. (Thus, drilling, mining, or other human activities that could conceivably breach the storage formation will be prevented.) Selective surface rlghts for this area might be leased for limited agricultural activities, such as grazing or farming. Additional restrictions on subterranean activities will be established over an area extending outward approximately two miles from the excavation. It is planned that, where possible, this larger area would be controlled through acquisition of perpetual subterranean rights as opposed to fee simple title, thus allowing unrestricted use of the land surface. 


\section{$1.2 \quad$ Design Assumptions}

For the purposes of this facility description, a reference for spent LWR fuel assembly isolation has been selected which uses bedded salt deposits located between 1500 and $2000 \mathrm{ft}$ below the surface. This repository will accommodate wastes in quantities roughly corresponding to the total waste generated through the year 1990. Figure A-I summarizes the types and quantities of wastes expected.

The reference concept assumes that all waste requiring shielded handling will arrive at the repository in stainless steel containers, called canisters. These canisters for the spent fuel assemblies are assumed to be $16 \mathrm{ft}$ long tubes of square cross-sections that are 6.5 in. on the side ( 6 in. inside width) for Boiling Water Reactor (BWR) fuel and 9.5 in. on the side ( 9 in. inside width) for Pressurized Water Reactor (PWR) fuel. ${ }^{2}$ The volumes of waste contained in the canisters will be $0.09 \mathrm{~m}^{3}$ of BWR fuel or $0.19 \mathrm{~m}^{3}$ of PWR fuel. Wastes that do not require shielding will 3 arrive at the repositiory in standard 55-gal drums, each containing about $0.21 \mathrm{~m}^{3}$ of waste. All waste received at the repository is assumed to be incombustible.

The repository will operate on a 5-day week, 3 shifts per day, 250 days per year. Multiple receiving and handling lines will be established for both shielded and low-level wastes. The waste handling facilities will allow reserve capacity for any irregularities in delivery schedules and surge storage capacity will be included in both the above ground and below ground facilities. The repository labor force is described in Appendix B.

The handling and disposition of excavated salt constitutes a major effort in the operation of the repository. It has been estimated that as much as 59 million tons of rock salt will be mined during construction of the spent fuel repository. Once the retrievability features of the repositiory are no longer required, a large portion of the excavated salt (approximately 60\%) will be used to backfill storage rooms and corridors. Preliminary studies have indicated that the most effective method of disposal with acceptable environmental impact may be controlled storage on the surface. Rail transport to an offsite permanent storage facility may be necessary. Interim storage onsite for a portion of the salt is provided as a potential source of backfill material during the initial years of repository operation. A plot plan of the repository site and surface facilities is provided in Appendix E.

1. Blomeke and Kee, "Projections of Wastes to be Generated", International Symposium of the Management of Wastes from the LWR Fuel Cycle, Denver, Colorado, July $11-16,1976).($ CONF-760701);

2. As directed by Battelle-Nor thwest Laboratories, memo by R. W. McKee, March 18, 1977. 
Canistered spent fuel assemblies (BWR and PWR) will be shipped to the repository in shielded casks in a manner approved by ERDA and NRC and in accordance with a certification of compliance that is granted by the Department of Transportation (DOT). The following criteria are assumed in unloading, handling, and emplacement of canisters at the repository:

- The canistered waste will be received in rail cars that have a maximum length over the couplings of $66 \mathrm{ft}$.

- The canistered waste will be delivered in casks, one cask to each rail car.

- The internal atmosphere of the cask will be air.

- The cask will be provided with connections that are suitable for venting internal pressure and for cooling of the canisters prior to opening the cask.

- The cask will be provided with a lid and a top sealing surface of a design to facilitate unloading from the top into a shielded transfer cell.

- The canister will be equipped with a standardized connector pin for lifting and handling.

- The thermal power of any single, spent-fuel canister will not exceed about 1000 Watts for 5 year old PWR fuel and about 325 Watts for 5 year old BWR fuel.

1.4 Criteria for Receiving Low-Level Waste

Low-level waste (LLW) will be shipped to the repository as DOT "Type B" or "Large Quantity" radioactive materials shipment in a manner that is approved by ERDA and NRC and in accordance with a certification of compliance that is granted by the DOT.

The following criteria are assumed to facilitate unloading, handling, and isolation of low-level wastes at the repository:

- Shipments will be received in ATMX-600 series rail cars, which serve as a secondary line of confinement resistant to possible collisions and fires.

- Returnable 8-ft $\times 8$-ft $\times 20$-ft cargo carriers will be used to facilitate unloading of the rail car. These carriers will be made of low-carbon, open-hearth, or electric steel that has been painted.

- There will be two cargo carriers per rail car.

- The rail car and the cargo carriers will be provided with fittings to permit withdrawal of a sample of air for analysis. 
- The maximum weight of the contents of a cargo carrier will be 20 tons.

- The waste container will be a steel drum made of low-carbon, openhearth, or electric steel (or an approved substitute) that has been painted.

- The minimum uncoated wall thickness will be 16 gauge. All body seams will be welded. Heads will be either gasketed or seal welded.

- Individual pallets will have maximum overall outside dimensions (including the skid) of $4 \mathrm{ft} \times 6 \mathrm{ft} \times 6 \mathrm{ft}$ high. The pallet will be braced and metalstrapped as necessary to protect against any detectable deformation of the unit or waste container sealing surfaces when the unit is being handled or stored in any orientation. The maximum allowable weight of a pallet will be $10,000 \mathrm{lb}$; each cargo carrier will contain a maximum of four pallets.

Containers that are known to contain liquids, potentially explosive chemicals, pyrophoric materials, oxidants (other than air), or sealed inner containers filled with gas under pressure will not be accepted.

\subsection{WASTE HANDLING OPERATIONS}

The types of wastes shown in Figure A-1 can be divided into two groups on the basis of their handling requirements. The low-level wastes will encompass the largest volume but will not require shielding or remote handling. On the other hand, smaller volumes of canistered spent fuel (PWR and BWR) are expected, but they will require remote handling. The design of the repository will include dual handling facilities to meet these requirements.

\subsection{Handling Operations for Canistered Spent Fuel Assemblies}

All canisters will arrive at the repository packed in shielded shipping casks. Individual canisters will be removed from their casks in shielded transfer cells, lowered to mine level through the canistered waste shaft, and transported to and buried in the salt bed chamber with a shielded transporter. Facilities involved in these operations include:

- Canistered waste building

- Canistered waste shaft

- BWR fuel mine

- PWR fuel mine

All operations from receipt of the shipping cask to loading canisters into the canistered waste shaft will be conducted in the canistered waste building. All handling operations within this building will be rcmotely controlled from adjacent operating rooms using manipulators and/or automated systems. 
The internal atmosphere of each cask will be sampled upon receipt of the cask at the canistered waste building. If this sample indicates radioactive contamination, the cask will be moved to the overpack transfer cell immediately following cooling. Casks with uncontaminated internal atmospheres will be taken to transfer cells. As the individual canisters are removed in the transfer cell, they will be visually inspected for shipping damage and subjected to surface contamination testing. Canisters that pass this inspection will be loaded into the mine feed conveyor system. A canister that is physically damaged or has surface contamination will be returned immediately to its cask, and the cask will be resealed and removed to the overpack transfer cell.

The overpack transfer cell will receive all casks containing damaged or contaminated canisters. Empty canisters, called overpacks, of a size sufficient to accept damaged canisters of either type will be stored in the overpack transfer gallery. These overpacks will be individually positioned and raised to be flush with the floor of the overpack transfer cell above. Once the overpack unit is positioned, the cask will be opened, and the damaged or contaminated canister will be loaded into the overpack unit. The overpack unit will be sealed and loaded into the mine conveyor system. All canisters will be transported to the appropriate mine and emplaced in the appropriate repository area. Remote control equipment will be used for all transfer operations. Shipping casks will be decontaminated as required at the overpack transfer cell. A schematic flow diagram for canistered waste handling is provided in Appendix E.

Low-Level Waste Handling Operations

The basic difference between LLW operations and operations for canistered spent fuel assemblies is that LLW do not require remote or shielded handling. Facilities involved in these operations include:

- Low-level waste building

- Low-level shaft

- Low-level mine

Nll operations from receipt of cargo carrier to loading waste containers into the low-level shaft will be conducted in the low-level waste building. Transfer cars will be used to transport cargo carriers; pallets will be handled with fork lifts.

The interior atmosphere and exterior surface of each cargo carrier will be checked for the presence of radioactive contamination upon its arrival at the low-level waste building. Although it is unlikely that contamination will be present, facilities will be provided to overpack drums that are contaminated or damaged. Cargo carriers and pallets will be decontaminated when required.

Pallets containing twelve 55-gal drums each will be removed from the cargo carriers and transported by fork lift to the head of the low-level shaft. After being lowered through the shaft, pallets and their contents will be transported to and emplaced in the low-level repository. A schematic flow diagram of low level waste handling is provided in Appendix E. 


\subsection{SURFACE FACILITIES}

The surface facilities described in this section encompass all buildings on the repository site. Structural and operational details for a similar facility may be found in Chapter I of the OWI report "Waste Isolation Facility Description" (Y/OWI/SUB-76/16506), which includes a discussion of the canistered waste building, the low-level waste building, the mining operations building, and the support buildings, including the adminstration building, the warehouse, and the gate house. Surface facilities for handling and disposal of excavated salt are also described. The surface facilities will constitute the only visible evidence of the repository and will be surrounded by a security fence. The fence encloses an area of approximately 200 acres.

\subsection{Canistered Waste Building}

The canistered waste building will provide the capabilities necessary to receive and handle canistered spent fuel assemblies that are shipped to the repository in shielded casks. In addition to those spaces provided for the handling and processing of canisters prior to delivery to the mine, space will be provided for support functions and activities not directly associated with canister handling. These spaces include a sample preparation room, a personnel check station, a change room, a shift foreman's office, and a maintenance and storage room. Access from these spaces to the operating gallery and the cask unloading area will be through airlocks. In the basement, rooms will be provided for mechanical equipment decontamination and for packing contaminated disposable items and contaminated liquid wastes. (An on-site radwaste management system is described in Section 9.4.) The hoist house servicing the canistered waste mine access shaft will be in a separate structure adjacent to the canistered waste building. Plans and sections for the canistered waste building are provided in Appendix E.

\subsection{Low-Level Waste Building}

The low-level waste (LLW) building will provide the capabilities necessary to receive and handle all low-level waste shipped to the repository in closed cargo carriers. In addition to spaces for the handling and processing of pallets prior to delivery to the mine level, space will be provided to support functions not directly associated with LLW handling. These spaces include a counting room, a personnel check station, a change room, an operations office, a heal th physics office, and a battery charge area. An exhaust fan filter room will be provided in a basement below the support area. The hoist house servicing the LLW mine access shaft will be in a separate structure adjacent to the LLW building. Plans and sections for the LLW building are provided in Appendix E.

\subsection{Support Buildings}

A mine operations building will be located near one of the mining (M\&M) shafts. This will contain a change room and shower facilities for mining personnel, a dispensary, a personnel check station, a storage supply facility, and office accommodation for all mine-related functions. The mine operations building will 
also contain general facilities for repair and maintenance of noncontaminated plant equipment and automotive equipment. A mine services building, smaller in size and scope than the mine operations building will be located near the other M\&M shaft to supply personnel facilities for men using that shaft. Such items as shower and change facilities will be included in this building. In the basement sections of both buildings will be located the mechanical equipment serving the mine ventilation systems, while the main switch gear, standby power generators and the central control and monitoring station will be in the mine operations building.

An open truck loading-unloading dock will be provided as well as an adjacent railroad siding. A full basement will be provided under the mine operations building to house the mechanical equipment serving the mine ventilation system, the repository main switch gear and standby power generators, and the central control and monitoring station.

The repository administration building will be located near the LLW building. It will house all central administrative personnel associated with the operation of the repository. Office space and a central lunch and conference room will be provided for repository management, engineering, accounting, personnel, safety, and payroll functions and for files and records.

Warehouses will be designed to serve the storage needs of the repository and to supply a maintenance shop for vehicles not associated with mining operation.

The gate house will be located at the fenced entrance to the repository. It will be the main check point for all employees, visitors, and automotive, truck and railroad traffic entering and leaving the repository. It will have annunciator and audible indicators for all alarm systems installed in the facility and will be tied into all communications systems used in the facility.

\subsection{Excavated Salt Disposal}

On-site surface storage will be provided for the mined salt, not only to maintain retrievability during the initial phases of operation, but also to act as a surge capacity for loading railroad cars. in lle inevitable situation of mining production being out of phase with railroad car capacity, in the event that off-site permanent disposal is selected. As shown in Appendix E, the surge stockpiles will be in two sections, one section for the requirements of each of the two mine shafts. The surface facilities for handling the excavated salt (the surge hoppers, belt conveyers and transfer houses) and the stockpiles will be inside a railroad car loop. The system of belts, hoppers and transfer will be designed so that the mined salt can go either direet from the inine to the stockpile, from the mine to the railroad car hoppers, from the stockpile back to the mine, or from the stockpile to the railroad car hoppers. The mined materials railroad handling system will not interfere with the reception of radioactive wastes. The stockpiles will accommodate approximately $22,000,000 \mathrm{ft}^{3}$ of excavated material. They will be provided with environmentally protective features such as PVC-plastic underliner and runoff control systems. 


\subsection{Railroad Yard}

A railroad yard will be provided, consisting of about 35,000 feet of track and all the related switchgear and blocks. A single track access to the site as far as the gatehouse will facilitate security and shipment controls, while within the yard three separate systems will be laid out:

- Canistered waste line
- $\quad$ Low level waste line
Mined salt line

For ease of scheduling within the site the mined salt line will be divided into two parallel lines over lengths sufficient to allow independent access to the mine surge and loading hoppers. Sidings will be provided sufficient to accommodate two days delivery of canistered waste and low level waste, and room for storage of approximately 200 mined-salt cars.

\subsection{SHAFTS AND HOISTS}

Five shafts will be sunk in connection with the operation of the facility. These will be the canistered waste shaft, the low level waste (LLW) shaft, two men and materials (M\&M) shafts for mining operations, and the ventilation exhaust (VE) shaft. These shafts all differ in size, design, usage, and functional constraints. Details of construction and operation are provided in Appendix C.

\subsection{Canistered Waste Shaft}

The canistered waste shaft will provide means for transporting the canisters of spent fuel assemblies (BWR and PWR fuel) from the canistered waste building to the subterranean storage levels. This shaft will have an inside diameter of $6 \mathrm{ft}$ and will be lined with $1 \mathrm{ft}$ of concrete. The top of the shaft will form an integral part of the canistered waste building.

The canistered waste shaft will have two subterranean accesses, PWR at elevation -1725 and $B W R$ at -1835 . From the lower shaft access three corridors branch out, leading to the BWR storage areas. Two of the corridors connect with the BWR storage area at elevation -1800; the other leads to an additional storage area at elevation -1725 . Likewise, three corridors branch out from the upper shaft access, leading to the PWR storage areas. Both PWR storage areas are at elevation -1725 .

From shielded receiving stations at the shaft accesses, the canisters will be transferred to shielded transporter vehicles for transport to the storage sites. The loading and unloading of the canisters into and from the specially constructed elevator cage used in the canistered waste shaft will be by remote control, permitting shielding of the canisters at all times. This waste handling area will be surfaced and sloped to sumps to permit rapid radwaste clean-up in case of accident. 
Facilities will be available to pump the radwaste cleanup solution to the surface for separation and solidification. The facility at mine level will be constructed of reinforced concrete and will provide parking facilities for the transporters.

\subsection{Low-Level Waste Shaft}

The purpose of the low-level waste shaft will be to provide a means for transporting the LLW pallets from the low-level waste facility to the low-level subterranean storage area (el. -1650). This shaft will have an inside diameter of $10 \mathrm{ft}$ and will be lined with $1 \mathrm{ft}$ of concrete. At the LLW storage level, there will be a receiving station where units will be picked up by lift trucks and loaded onto a transporter.

\subsection{Men and Material (M\&M) Shafts}

Two similar shafts will be provided to handle men and mined material, each designed to perform the following functions:

1. provide access for men and equipment into and out of the subterranean storage areas

2. provide salt hoisting for the mining operation

3. serve as a ventilation air supply duct.

To perform these functions the $M \& M$ shafts will be subdivided into three main compartments (men and equipment, salt hoisting, and air supply) and two auxiliary compartments for cage counterweights and for the manway. The shafts will have an inside diameter of $26 \mathrm{ft}$ and will have a $1 \mathrm{ft}$. thick concrete liner.

The men and equipment compartment for each shaft will be sufficiently large to accommodate a cage with a capacity for 70 men. The compartment will be large enough to permit the lowering and raising of large pieces of equipment either in assembled or partly disassembled form.

The air supply compartment in each shaft will have a cross sectional area of 140 sq. $\mathrm{ft}$. and will be made completely airtight with respect to all other shaft compartments by a concrete divider wall. All other compartments will not be airtight with respect to each other.

Two auxiliary compartments will be provided adjacent to the men and equipment compartment. One compartment will include a manway, which will be an emergency exit for all mine personnel, together with space for utilities. The other auxiliary compartment will contain counter weights for the salt hoist. 


\subsection{Ventilation Exhaust Shaft}

Ventilation air in the mine-level area will be exhausted through this shaft into filtration systems located on the surface. This shaft will have an inside diameter of $26 \mathrm{ft}$, will be concrete lined, and can serve for emergency ingress to or egress from the mine. Ventilation air from the surface buildings will also be exhausted from this facility, which will have a stack approximately $360 \mathrm{ft}$. in height.

\subsection{MINE FACILITIES}

The subterranean portion of the repository encompasses a total affected gross area of approximately 2,000 acres. A master plan is shown in Appendix E. The mine layout and storage sequence design is a conventional room-and-pillar layout and incorporates the requirements of mine ventilation, mine opening stability, thermal effects, and efficient use of excavated space to allow for surcharge of mining and haulage equipment. A modular approach to the mine development allows the simultaneous performance of mining activities and waste storage operations. Excavation of one "panel" of storage rooms proceeds without interfering with the storage operations in the previously excavated panels. All mining activities involved in initial phase repository construction will be completed prior to emplacement of any radioactive wastes. Construction corridors in the vicinity of the shafts and mined material conveyors will not intersect waste haulage corridors.

To guarantee shaft stability, a 150-ft radius safety zone is designated around each shaft. All travelways, except those leading to the shafts, pass outside this zone.

All storage rooms receiving canistered wastes are designed to have only one entry. This provides positive control heat, ventilation, and exhaust for each room. Rooms for low-level waste storage are designed as an open-grid system to permit easy storage without impeding ventilation performance.

\subsection{BWR Fuel Waste}

The BWR mine is located so that its heating effects do not impact the operation of the shafts or on mine areas for other waste types. Access to the mine consists of three BWR main corridors originating from the receiving station at the foot of the canistered waste shaft. The M\&M main corridors run parallel to these corridors in each of the BWR storage areas. Each BWR main corridor connects with branch corridors from which extend the storage rooms. Each storage room will be 560 feet long, 25 feet high and 36 feet wide. The pillar between two adjacent storage rooms will be 42 feet wide. 192 canisters will be stored in each room in vertical holes bored into the floor of the room at $9 \mathrm{ft}$ centers transversely and 3 across with $8 \mathrm{ft}$ centers along the longitudinal axis. Details of the configuration, as well as of the holes and the liner sleeves provided for retrievability, are shown in Appendix E. 


\subsection{PWR Fuel Waste}

The PWR material will be received at the upper receiving station of the canistered waste shaft, located $110 \mathrm{ft}$ above the receiving facility for BWR. The PWR area main corridors run parallel with the main corridor for men and materials. Storage rooms will accommodate canisters at $12 \mathrm{ft}$ centers transversely and 16 $\mathrm{ft}$ centers along the longitudinal axis of each room. 62 canisters will be stored in each room. Storage holes and liner sleeves will be similar to those used in the BWR mine.

\subsection{Low-Level Waste}

The LLW material will be delivered to the LLW storage area from the receiving station of the LLW shaft through a main corridor. The M\&M main corridor will run parallel to the LLW main corridor. The main corridors are connected by branch corridors similar to the other two mines except that the rooms will be on an open-grid system. Each room is divided into nine pallet storage areas. These areas will be $16 \mathrm{ft}$ wide $\times 48 \mathrm{ft}$ long, accommodating 64 pallets (768 drums) and allowing $11-\mathrm{ft}$-wide longitudinal aisles on each side to permit convenient entry. There will be 10-ft-wide transverse aisles between the pallet storage areas for easy access. The pallets will be stacked two pallets high. Approximately 7000 drums per room will be accommodated.

The receiving stations for LLW will provide space for transfer of the LLW pallets from the cage to the transporter. The walls, floors, and roof of the LLW station will be built of reinforced concrete and will be structurally tied into the shaft concrete. There will be an adequate area for parking trucks, personnel rest rooms, and a small workshop adjacent to the receiving station. The station will be isolated from the main entry by a double-door air lock.

\subsection{Mining Operations}

After initial repository construction, use of explosives in the mine will not be necessary. Electrically powered continuous mining machines will be used to construct the storage rooms. A maximum production capability of about 6.4 million tons of salt per year is expected. Diesel lrucks will transport the mined salt to branch corridor conveyors, which will be frequently extended so that the truck haulage distances are maintained as short as possible.

At each level branch corridor conveyors will transfer the salt to roof-suspended main line conveyor systems that transport the salt to an underground storage bin. There will be a salt storage bin in both the PWR mine and the BWR mine. In each mine, a reclaim conveyor beneath the storage bin will transfer the salt to a surge bin, where it will be conveyed to loading pockets and hoisted to the surface through the respective $M \& M$ shaft. A separate salt-handling system, consisting of storage bin, surge bin, and conveyors, will be developed for each $M \& M$ shaft. Men, materials, and equipment entering or leaving the mine will use the appropriate $M \& M$ station. There will be a station on the level of each of the M\&M main corridors and these stations will be similar to those for the 
LLW facility. These shafts will be separated from their station by a steel door for personnel safety. The lock separating the station from the mine will be of fireproof construction and will also serve as a refuge for mine personnel in case of fire or other emergency situations.

\subsection{VENTILATION SYSTEMS}

\subsection{Subterranean Ventilation Systems}

Fresh air will enter the repository through the air supply compartments of the two M\&M shafts. A total of approximately $1,000,000 \mathrm{cfm}$ will be provided to the repository and will be divided as follows:

- $\quad 50,000$ cfm to the LLW mine
- $\quad 550,000$ cfm to the PWR mine
- $\quad 350,000$ cfm to the BWR mine
- $\quad 50,000$ cfm to mining service areas

The ventilation supply facilities will be at the top of each $M \& M$ shaft. Each supply fan will have a nominal capacity of $200,000 \mathrm{cfm}$, a motorized shutoff damper, and a 150 bhp motor. The fans will be connected via a plenum in the facility. The ventilation building for the PWR shaft will have four of these fans (one is a standby) rated at $3 \mathrm{in.}$ w.g. total pressure; the switchgear to be installed will have a capacity of $350 \mathrm{kw}$. The ventilation building for the BWR shaft will have three of these fans (one is standby) rated at $1.5 \mathrm{in}$. w.g. total pressure; the switchgear to be installed will have a capacity of $250 \mathrm{kw}$. Each building will have the usual equipment such as ventilation, lighting, fire protection, drainage, a maintenance area for servicing the fans, and inlet louvres (bird screens). The fan shutoff dampers will be designed so that their operation does not bring about pressure waves in the mine. Supply air flow rate will be monitored; an alarm system will be activated when flow falls below a preset minimum flow rate.

All exhaust from the repository will be through the upcast ventilation exhaust shaft. The exhaust ventilation building will be located at the top of this shaft and will house the exhaust fans and filter trains, fan dampers, switchgear room, provisions for building lighting, ventilation, fire protection, entranceway for maintenance personnel and roof hatch for equipment removal. Each exhaust fan will have a nominal capacity of $200,00 \mathrm{cfm}$, a $750 \mathrm{bhp}$ motor and a $300 \mathrm{sq}$. $\mathrm{ft}$. motorized shut-off damper. The maximum fan total pressures will be approximately 15 in. w.g. at $200,000 \mathrm{cfm}$. It is expected that the fan duty will vary from $5 \mathrm{in}$. w.g. total pressure to $15 \mathrm{in.}$ w.g. depending on the degree to which the filters are clogged.

Each filter train will contain roughing filter banks and two HEPA filter banks in series. The fans and the fil ters will be connected via a plenum in the building. Five filter trains and five fans will normally be in operation while the sixth train of filters and fan are being serviced or held in standby. Any "off-gas" 
from the surface waste handling facitilities will be introduced at the top of the upcast shaft to allow mixing prior to the filters. After filtration, the exhaust air will be discharged to the atmosphere through the $360 \mathrm{ft}$. high exhaust stack that is continuously monitored to detect any radioactivity or noxious gases.

A schematic diagram of the repository ventilation system is shown in Appendix $\mathrm{E}$. It is expected that a peak of 19 mining machines will be working in the mine at once. One machine would be working in the LLW area. Eleven machines would be working in the PWR area with an additional one working on the PWR ventilation. Five machines would be working in the BWR area with an additional one working on the BWR ventilation. It is expected that the LLW ventilation will be finished prior to the peak need for mining machines. Nine thousand cfm was used as the ventilation requirement for each canister transporter operating in the mine. This was equivalent to $78 \mathrm{bhp}$ per transporter and a ventilation requirement of $115 \mathrm{cfm}$ per bhp. It is expected that a maximum of twenty transporters will be working in the mine at once. This figure was developed using assumptions concerning the transporters' average operating speed and the number of canisters to be stored per day. Using $9000 \mathrm{cfm}$ per transporter the ventilation required for twenty transporters will be $180,000 \mathrm{cfm}$. The ventilation requirement for dust collection will be $40,000 \mathrm{cfm}$. The ventilation requirement for losses (recirculation) will be 40,000 cfm.

This ventilation concept is similar to the one developed in the report of September 1976 (Y/OWI/SUB-76/16506) with the air being supplied through corridors and removed by a perimeter exhaust system. The air will be supplied to the mine through isolated airways in the two 26 foot diameter M\&M shafts. The supply rates will be $600,000 \mathrm{cfm}$ through the shaft adjacent to the PWR area and $400,000 \mathrm{cfm}$ through the shaft shaft adjacent to the BWR area. The area of the isolated airway in each ventilation shaft is approximately 140 sq. $\mathrm{ft}$. The resulting air velocities will be $4300 \mathrm{fpm}$ (PWR shaft) and $2900 \mathrm{fpm}$ (BWR shaft).

The exhaust duct systems will be at the same level as the areas of the mine they are ventilating. A single extension pass from the newly completed room to the branch duct will be made with the mining machine. The resulting outlet area of this room will be great, thus greatly increasing its ventilation capacity. There will be a a automatic damper at the end of the branch duct similar to the one at the end of the branch corridor. The presence of strata will probably cause some deviation from the design plane of the layout.

All of the exhaust ducting will be 36 feet wide and 12 feet high. These dimensions were chosen principally for ease in mining long runs; however, it provides an excellent area for ventilation, causing smaller pressure drops. The end to end spacing of the rooms will be 116 feet with a 40 foot pillar between the branch duct and the end of the room. Exhaust ducts, such as those that must pass under the main corridors, will have no uphill or downhill slope greater than seven degrees (12\%). Mining at slopes greater than this is uneconomical because of the consequent production slowdowns and additional equipment problems, etc. Parallel exhaust ducts will have 42 foot pillars between them. 
The branch ducts will be mined off the main corridor. After one is completed the portion of the perimeter duct associated with it will be mined and tapped into that completed with the previous duct. The branch duct automatic damper will then be installed. Finally, the branch duct will be permanently sealed at the main corridor end. This construction sequence will require that a portion of the exhaust header duct be compeleted prior to the completion of the first branch duct.

In the event it is necessary to enter a panel af ter canister storage, the automatic damper at the junction of branch corridor that serves the panel and the perimeter exhaust duct will be opened. The temporary bulkhead at the junction of the main and branch corridors will then be removed, thus flushing the branch corridor. After the branch corridor is flushed (this will be determined by temperature or air change measurements), the branch corridor automatic damper will be closed and the branch duct automatic damper opened, thus simul taneously flushing all the rooms in the panel. If it is necessary to direct more airflow through a room than this approach provides, then as many other rooms as is necessary will be bratticed off from the branch corridor. The repository will be maintained at a negative pressure relative to the atmosphere by adjusting the supply fan pressures relative to the exhaust pressures.

\subsection{Ventilation of Surface Structures}

All surface structures which will contain the handling of radioactive wastes will be operated at a negative pressure with respect to the atmosphere. Ventilation flows will be controlled by pressure differential from areas of low contamination potential to areas of successively higher contamination potential. Exhaust air will be processed through a roughing filter bank and two HEPA filter banks in series prior to discharge. Duplicate filter banks and exhaust fans will be provided, with both fans connected to the standby power distribution system. Each structure will have a ventilation system independent of other structures. All ventilation exhaust air from surface buildings containing waste or waste handling facilities will be exhausted through the ventilation exhaust facility serving the below-ground mining areas. This will provide enhanced dilution should there be accidental release of radioactive off-gas due to the rupture of spent fuel elements.

\subsection{LAND IMPROVEMENTS}

7.1 Site Clearing, Grading, and Landscaping

Grading will be necessary during construction to provide roads, parking areas, drainage ditches and adequate surface drainage control.

\subsection{Roads and Parking}

Two-lane access roads will connect all major buildings on the site to the nearest existing public thoroughfares and a fire road will be provided for access to all other structures. Parking areas will be provided at all major centers of plant activity. 


\subsection{Railroad Access}

Railroad access will be provided for delivery of waste shipments to the Canistered Waste Building and to the Low Level Waste building, for Warehouse and the Mine Operations and for activities associated with the disposition of mined salt. All railroad trackwork will be designed in accordance with the current standards of the American Railroad Engineering Association Specifications.

\section{$7.4 \quad$ Fencing}

Chain link exclusion fencing, including all accessory appurtenances, will be provided around the repository site to maintain access and operational control within the repository. Additional measures to provide site security will be part of the final design.

\subsection{Storm Water Runoff}

Storm sewers with free outlets to receive water courses will be provided to convey water collected by catch basins, roof drains, and subsurface drainage systems for the "probable maximum flood" condition. Areas disturbed by construction activities will be subgraded to remove topsoil and grading will be provided to eventual finished contours. Topsoil will be applied to all disturbed areas and these areas will be replanted with vegetation.

\subsection{UTILITIES}

\section{1}

Domestic Water

Potable water will be supplied to the site from two sources to minimize the chance of supply interruption. Storage tanks will provide emergency water reserves on site.

\subsection{Electric Power}

Electric power requirements are divided into three general categories:

- normal power will be supplied by the local electric utility.

- standby power will be provided by generators (diesel or gas turbine driven) having their own fuel supply and automatic switchover and starting system.

- uninterrupted power will be available from either rotary motor generator sets or standby batteries.

During normal operation, electrical power will be purchased from a local utility in order to supply lighting, water heating, space heating, monitoring instrumentation, electrical equipment operation and steam generation. 
Standby power requirements will include electricity for confinement equipment (controls, fans, etc.), for radiation monitoring instruments, for communication systems, for both underground and surface facilities, and for the personnel hoist system serving the men working below ground and materials.

Standby power will start automatically and pick up the appropriate loads within 3 minutes of a power failure. Standby power feeders shall be located underground in separate conduits from normal power.

There are only two requirements currently anticipated for uninterrupted power at the Repository. The first is for sufficient lighting for personnel to exit from structures and for personnel to start standby power equipment, if necessary. The second requirement is for sufficient power supply to maintain communications for both the normal mining and emplacement as well as security operations and to provide for control instrumentation among all the principal facilities of the repository. All personnel working underground will be equipped with miner's lamps.

\subsection{Sanitary Waste Disposal}

Sanitary waste, not contaminated with radioactivity, includes waste from toilets, lavoratories and clean showers, lunch room sinks, janitor's sinks in nonrestricted areas, and drinking fountains. Storm drainage will not be included in this system. Secondary treatment of all sanitary wastes will be provided on site.

Contaminate waste and disposable contaminated equipment will be processed and packed within the surface facilities, and stored in the LLW mine.

\section{$8.4 \quad$ Fuel}

Diesel oil is the only fuel to be stored on site. This oil will be for diesel operated equipment and for emergency $4 \mathrm{MW}$ electric power generation. Diesel oil for the equipment will be stored in a common tank at the surface. Daily requirements underground will be transported in approved portable tanks. The standby diesel-electric generators will have a fuel supply that is separate from all other uses.

\section{5 $\quad \underline{\text { Steam }}$}

Low pressure steam (100 psig) will be provided for waste evaporation, and other service as required. The installed capacity of the steam system will be 200,000 pounds per hour.

\subsection{Communications}

Normal communication between the various areas of the Repository, both surface and mine level facilities, will be over commercial telephone lines. A central monitoring and control station will be located in the Mine Operations Building. Radiation monitoring, fire and confinement air handling system alarms will be transmitted to a central panel board at this station and to the gate house. Alarm systems will be initiated automatically by signals from monitoring instrumentation, or manually from the central console. The security system will have automatic energency communication gear for use in the event of a commercial power outage. 


\subsection{ACCIDENTS, CONFINEMENT AND SAFETY CRITERIA}

\subsection{Accident Situation}

An accident situation has been defined and used as a basis for design and for testing the confinement and safety criteria. The accident situation scenario is that of a single canister of spent PWR assemblies being involved in an accident, rupturing in the process $50 \%$ of the full elements within the canister. The important volatile fission product (VFP) releases from spent BWR and PWR assemblies that are at least 5 years old are $\mathrm{Kr}-85$ and $\mathrm{l}-129$, the PWR assemblies releasing more than the BWR assemblies. The $\mathrm{Kr}-85$ isotope would account for 1800 curies per accident, while the I- 129 would account for $2.5 \times 10^{-3}$ curies per accident. The release of these isotopes in any part of the facility that handles the canistered spent fuel assemblies, above or below ground, was investigated from the aspect of ventilation and personnel safety and checked against allowable levels of release into the atmosphere, as defined in the Code of Federal Regulations, Title 10, Part 20. Consideration was given to both restricted and unrestricted areas, using "worst case" meteorological conditions.

\section{$9.2 \quad$ Confinement Systems}

The confinement systems of the Repository will be used to restrict release of radioactivity to the environment during normal and accident conditions. The following criteria will apply to confinement systems:

- Two barriers will be maintained between the radioactive waste and the environment at all times.

- Structures will be designed to prevent the leakage of radioactivity to the environment in the event of an accident.

- Under emergency conditions, structures will be maintained at a negative pressure relative to the atmosphere. For increased reliability and simplicity, structures will normally operate in this condition.

- Air in structures will flow from areas of least contamination potential to areas of increasing contamination potential.

- Recirculation of air within zones of similar contamination potential, or from zones of lesser to greater contamination potential is permitted, if air is passed through HEPA filters.

- Ventilation systems will be backed up by standby systems to maintain confinement in the event of fan break down, filter failure, or normal power outage.

- $\quad$ Air discharged from confinement systems will be exhausted through prefilters and HEPA filters. Air from areas of highest contamination potential (low level waste handling rooms or canister transfer cell exhaust) will be exhausted through two individually testable HEPA filter banks in series. Air which is normally clean but which has the potential of becoming slightly contaminated will require only one bank of HEPA fil ters. 
- Corrosive agents or moisture in the exhaust air capable of damaging the filters will be removed or neutralized prior to discharge to the fil ters.

- Confinement systems will be designed to maintain their integrity in the event of fire.

\subsection{Monitoring}

Instrumentation will be provided at the repository to perform the following radiological monitoring functions:

- Surveying all incoming and outgoing personnel, material, and equipment for possible contamination or unauthorized transport of fissile material.

- Monitoring the environment within facility buildings and subsurface storage areas, and for initiating appropriate alarm signals in the event of a malfunction.

- Monitoring all effluents from buildings and the mine.

- Monitoring the Repository property.

\subsection{On-site Radwaste Management}

Waste management equipment will be included in the facility to handle wastes from the following sources:

- Normal Operations - These are primarily compressible solid wastes, e.g., gloves, bottles, protective clothing, swipes, etc.

- Decontamination - Primarily liquid wastes generated by clean-up operations following an accident involving a release of radioactivity. This category would include wastes generated by the decontamination of equipment for maintenance.

There are no other radioactive waste sources in the present design.

The nature of the operations relating to radwaste equipment may be anticipated to be a rather constant, low-level demand from normal operations interrupted by peak loads many times the normal requirements caused by large area decontaminations following accidents.

Based on the waste sources and the anticipated operational demands, the following radioactive waste management equipment will be required.

1. Two (2) waste balers - one in each surface facility.

2. Surge Tanks - capable of holding the maximum amount of decontamination wastes anticipated. 
3. One (1) waste evaporator of approximately 5gpm capacity.

4. A radioactive waste solidification system capable of processing the normal quantities of liquid wastes generated without evaporation.

The waste balers are used to minimize the volume of compressible solid wastes, and will be located such that they are readily accessible by drum handling equipment.

The surge tanks will be located in the canistered waste building. NRC Regulatory Guides 1.26 and 1.28 and to NRC Eflluent Treatment Systems Branch Position Paper $11-1$ will be used for regulatory design requirements.

The evaporator will be located in a separate room near the solidification system. It will be designed to handle a variety of wastes with different chemical properties.

The solidification system will be located below grade elevation, with ready access by drum handling equipment and the required equipment to facilitate cement unloading procedures. The solidified waste will be transferred to the low level waste facility, since the product of the waste solidification system will be low level wastes.

Considerable attention will be given to the practical problems of decontamination, both above ground and below ground. In areas to be washed down, the walls and floors will be waterproofed, the floors will be sloped to sumps, lighting will be waterproof, and steam and/or water connections will be readily available. Operator exposure will be considered in equipment and facility design and will be factored into proposed decontamination schemes.

\subsection{Protection of Repository Personnel}

The following measures will be taken to protect repository personnel:

- Posted, controlled access "Radiation Zones" wil! be established in those areas in which the weekly averaged penetrating radiation dose rate is greater than $1 \mathrm{mrem} / \mathrm{hr}$.

- Posted, controlled access "Contamination Zones" will be established in those areas that have significant potential for the transfer of surface contamination. Controls will be accomplished through the use of physical confinement barriers and, where possible, the maintenance of a flow of air in the direction of increasing contamination potential. Wherever possible, a facc vclocity of air of at least 150 feet per minute will be provided to isolate zones of potential contamination from their surroundings.

- $\quad$ "Regulated" zones with physical confinement barriers will be provided between contamination zones and the environment. Such zones will consist principally of air locks and change rooms for entry and egress of personnel and materials. 
- Area radiation monitors equipped with alarms will be provided in all areas in which there is potential hazard from penetrating radiation or air-borne contamination.

\subsection{Protection of the Public}

The public will be protected from exposure to radiation or radioactive materials originating from the repository by the following measures;

- There will be no discharges of radioactive materials to the sanitary sewer system.

- All solid and liquid wastes generated within the repository will be processed and buried in the mine.

- Releases of airborne radioactive materials from the repository will be maintained at the lowest practical levels, and well below levels required in applicable standards.

\subsection{Mine Safety}

The prescribed standard governing mine and tunnel safety for the Federal Repository is the Federal Heal th and Safety Standards, "Metal and Non-Metallic Underground Mines", 30CFR57. The California State Mine Safety Orders will be used as a guideline on mining safety whenever a particular subject is not covered by the Federal Code 30CFR 57. 
APPENDIX A

MINE LAYOUT AND DEVELOPMENT

Figures

A-1 Characteristics of : Reference Repository

A-2 PWR Spent Fuel Storage Schedule

A-3 BWR Spent Fuel Storage Schedule

A-4 Low Level Waste Storage Schedule

A-5 Storage Schedule By Rooms

A-6 General Plan of Mine Storage Panels

A-7 Approximate Mining Schedule/PWR

A-8 Approximate Mining Schedule/BWR

A-9 Mining Schedule

A-10 Summary Projections of LWR Spent Fuel Production 


\section{Appendix A}

\section{Mine Layout and Development}

\section{General Plan}

It was initially decided that the configuration of the mine storage areas for the PWR and BWR spent fuel units would be similar to that envisioned for the high-level waste in a previous report prepared by Parsons. ("Waste Isolation Facility Description," Y/OWI/SUB-76/16506).

In this layout scheme (Appendix E), three "main" corridors extended the leng th of the mine. The middle or "men and material" (M\&M) corridor serves as a travelway for all vehicles and equipment associated with the mining operation. In addition, it contains an overhead conveyor for transporting the mined material to the mining shaft. On either side of the $M \& M$ corridor, separated from it by a 90 foot pillar, are the PWR/BWR main corridors. These corridors are used only by the special transporters that deliver the spent fuel units from the shaft receiving station to the proper burial point. All three main corridors are 36 feet wide and 25 feet high.

The storage "panels,". adjacent to the main corridors on both sides, consist of a "branch" corridor and adjoining storage "rooms". Each room is 36 feet wide, 25 feet high and 560 feet long. Successive rooms are separated by a 42 foot pillar, resulting in a gross area of approximately one acre per room.

\section{Determination of Mine Layout}

Waste receipt schedules for PWR and BWR spent fuel are shown as Figures A-2 and A-3 respectively. Projections of LLW are shown in Figure A4. The columns labeled "Placed at Repository" are essential to determining the size of the storage panels (i.e. the number of rourns per panel), since a pancl must be completely mined before the incoming waste units can be buried there.

The receipt schedules were prepared assuming a five year storage capacity at the individual reactor sites for the spent fuel units. Prior to initial operation of the repository in mid-1985, these on-site storage pools will reach capacity. The overflow spent fuel units (greater than 5 years old) will be managed in a manner yet to be determined. As shown in the schedules, the greater-than-5-yearold backlog is 9110 units for PWR and 12830 units for BWR. 
In each of the first 5 years of the repository operation, the number of spent fuel units to be buried will equal the number of units produced 5 years earlier. Note that during this period the greater-than-5-year-old backlog remains constant. In each of the remaining 5 years $(1991-1995)$ the number buried equals the output 5 years previous plus one-fifth the greater-than-5-year-old backlog. Following the schedule, this overflow backlog will be depleted when the repository is filled (March 1995). At this point the area of the underground facility is approximately 2000 acres.

Using the waste receipt schedules, a table was prepared $(\mathrm{A}-5)$ showing the number of storage rooms that must be completed by a given year. The number of canisters of spent fuel to be placed in each storage room was taken as 62 for PWR and 192 for BWR. After several trials, the following layout plan was devised: In the PWR mine the first panel consists of 30 storage rooms, the next 6 panels each have 34 rooms, and each of the remaining 14 panels has 50 rooms; in the BWR mine the first 2 panels have 19 rooms, the next 2 have 18 rooms, and the remaining 6 panels have 50 rooms. A general plan showing the panel numbers is presented as Figure A-6. The number of the panel that must be completed by a given year can be found in the appropriate column in Figure A-5.

The above scheme insures that:

1. The first storage panel can be completed by the scheduled starting date for the repository (mid 1985), assuming that mining of the panel can begin mid 1981.

2. Subsequent panels can be completed in time to receive incoming canisters. In computing the length of time required to mine a panel, it was assumed that a mining machine could excavate 400,000 tons of material per year (see Appendix B). Under normal circumstances, a panel can be mined by only one machine at a time. On this basis an 18 or 19 room panel requires 2 years, a 30-room panel 3 years, a 34-room panel 3.5 years, and a 50-room panel 5 years to mine. An additional $1 / 2$ year was allowed for drilling of the placement holes and for ventilation hook-up.

3. The peak in the mining rate occurs late in the mine development. The approximate mining schedules for the PWR and BWR mines are shown in Figures A-7 and A-8. These schedules show that the mining rate, as evidenced by the number of mining machines in operation, reaches a peak in the years 1988-1989. If larger panels were used the peak would occur earlier. This is undesirable since it would entail a larger number of mining machines being used during the tirst few years of operation, the beginning of the scheduled 5-year monitoring period for the repository. 
4. The main corridors are kept at a reasonable length. If smaller storage panels were used, the main corridors would consequently be longer. Problems would then develop with the canister placement (increased cycle time for the transporter) and ventilation (increased air pressure drop).

5. The total gross area of the underground facility is approximately 2000 acres. Under this limitation, spent fuel and low level waste units delivered to the year 1995 can be accommodated. This represents reactor output to the year 1990.

\section{Initial Development}

Initial development for the mine includes the following: All corridors connecting the shafts with the storage areas, a parking and service area for the canister transporters, a service area for the maintenance of all mining vehicles and equipment, and dual salt-handling systems consisting of storage bin, surge bin and conveyors (see Appendix B). A study was made to determine the length of time required to complete this stage. The study was similar to that made for the storage panels, except that reduced mining rates were assumed; i.e. less than 400,000 tons per year.

Paying close attention to the sequence of excavation, it was found that the initial development could be completed two years after completion of the M\&M shafts. Also the mining of the first panel could commence $11 / 2$ years after completion of the M\&M shafts. Five mining units would be required during the first year of initial development and two units for the second year.

\section{Adjusted Mining Schedule}

A plot was made (Figure A-9) of the number of mining machines required for each year using the approximate mining schedules for the PWR and BWR mines and the number required for initial development. Additionally, it was assumed that an average of one mining unit in operatjon continuously from 1981 to 1992 could mine both the low level mine ( $1.0 \times 10^{6}$ tons) and the underground ventilation ducts $\left(3.0 \times 10^{6}\right.$ tons). In order to insure a steady, rather than erratic, increase in the mining rate from 1980 to 1986 and a steady decline to 1993, an adjustment made to the graph as shown by the dashed line. The resulting values for yearly machines are shown at the bottom. The annual mining rate is also shown. 
Characteristics of Reference Repository

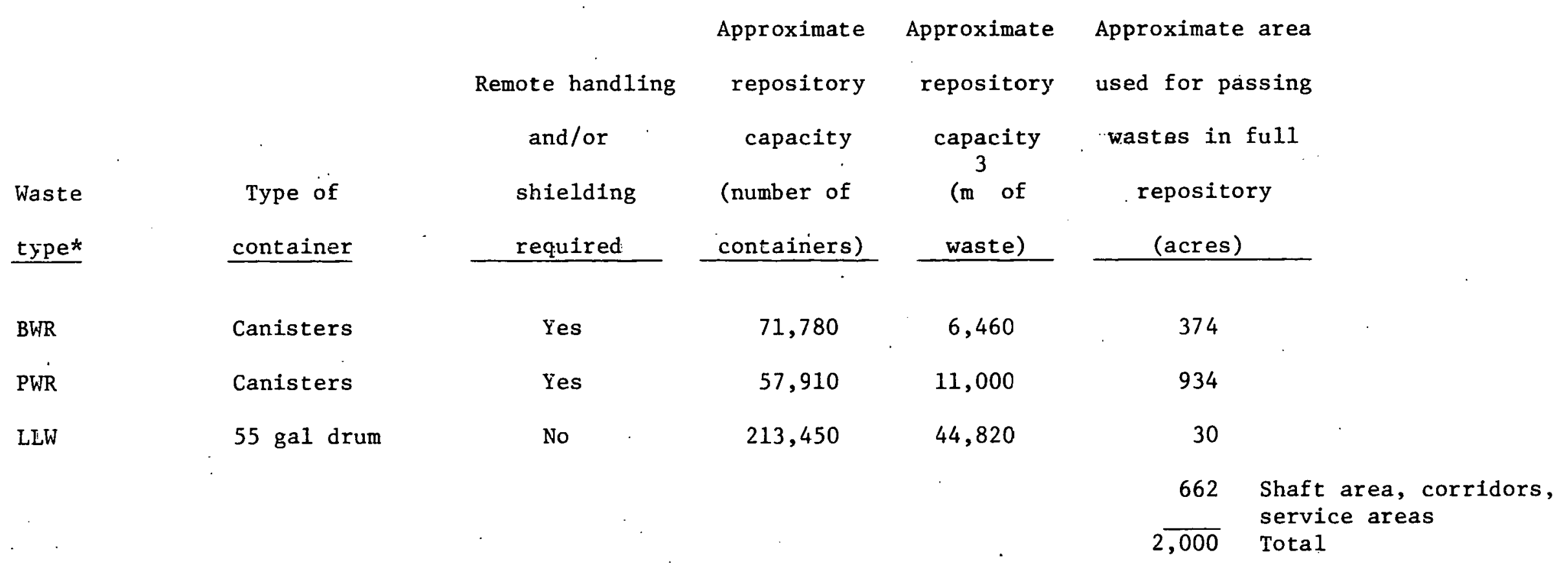

$* \mathrm{BWR}=$ boiling water reactor $; \mathrm{PWR}=$ pressurized water reactor $; \mathrm{LLW}=1$ low-level waste. 
Table A-2

PWR

APPROXIMATE SPENT FUEL PRODUCTION AND STORAGE

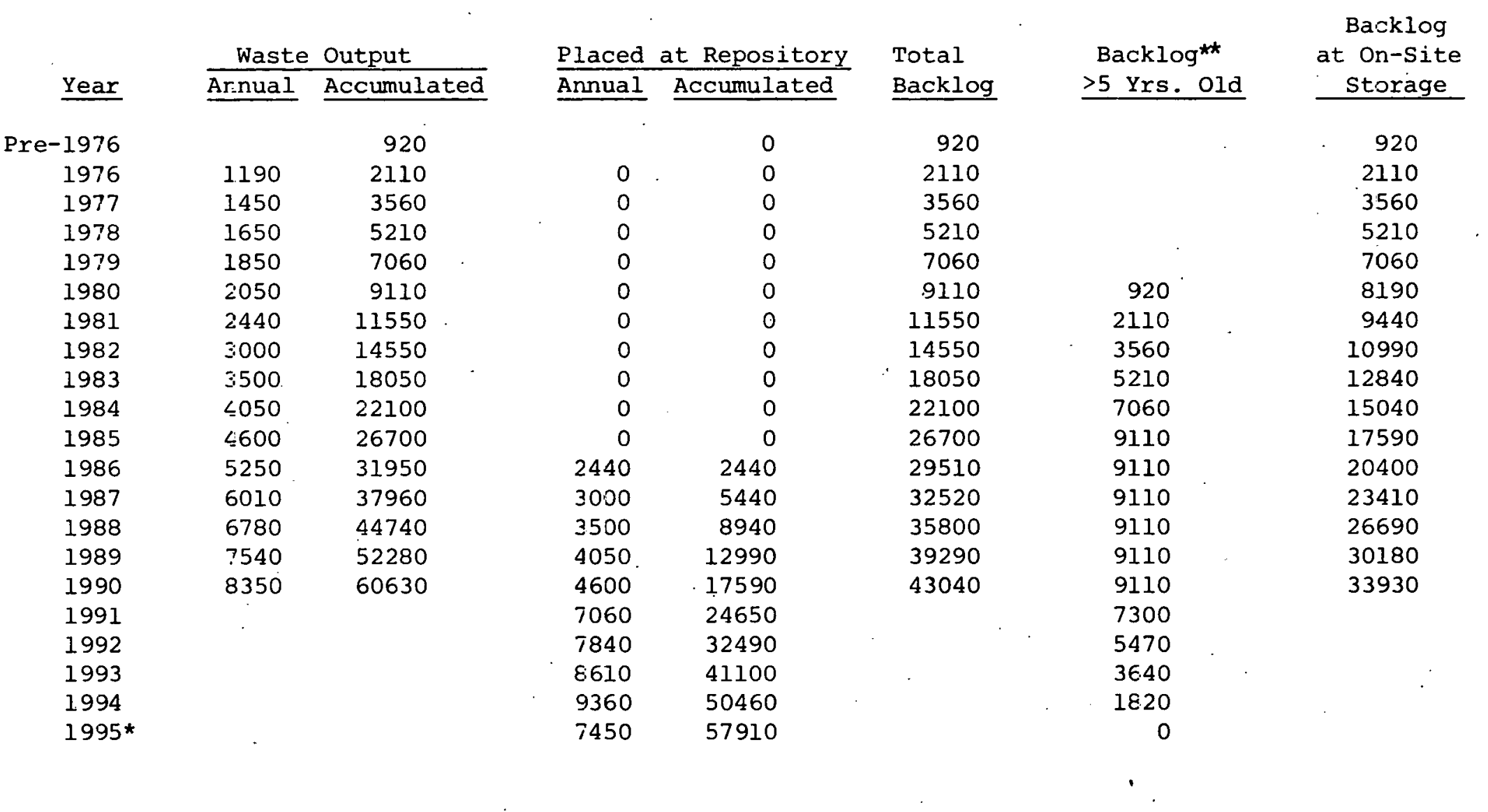

- Indicated year denotes period ending middle of that year, i.e., $1985=\mathrm{mic} 1984-\mathrm{mid} 1985$

*Repository operates 3/4 of year 1995, to March 1995.

**Assumed to be stored at some location other than the reactor site pools, for the purposes of this study.

Based on figures from Blomeke \& Kee Tables. (Projections of Wastes to be Generated, Internationai Symposium on the Management of Wastes from the LWR Fuel Cycle, Denver, Colorado, July 11-16, 1976.) 
Table A-3

BWR

APPROXIMATE SPENT FUEL PRODUCTION AND STORAGE

\begin{tabular}{|c|c|c|c|c|c|c|c|}
\hline & Waste & Output & Placed & at Repository & Total & Backlog * * & $\begin{array}{c}\text { Backlog } \\
\text { at On-Site }\end{array}$ \\
\hline Year & Annual & Accumulated & Annual & Accumulated & Backlog & $\geq 5$ Yrs. old & Storage \\
\hline Pre-1976 & & 2910 & & 0 & 2910 & & 2910 \\
\hline 1976 & 1440 & 4350 & 0 & 0 & 4350 & & 4350 \\
\hline 1977 & -760 & 6110 & 0 & 0 & 6110 & & 6110 \\
\hline 1978 & 2000 & 8110 & 0 & 0 & 8110 & & 8110 \\
\hline 1979 & 2240 & 10350 & 0 & 0 & 10350 & & 10350 \\
\hline 1980 & 2480 & 12830 & 0 & 0 & 12830 & 2910 & 9920 \\
\hline 1981 & 2950 & 15780 & 0 & 0 & 15780 & 4350 & 11430 \\
\hline 1982 & 3630 & 19410 & 0 & 0 & 19410 & 6110 & 13300 \\
\hline 1983 & 4240 & 23650 & 0 & 0 & 23650 & 8110 & 15540 \\
\hline 1984 & 4900 & 28550 & 0 & 0 & 28550 & 10350 & 18200 \\
\hline 1985 & 5560 & 34110 & 0 & 0 & 34110 & 12830 & 21280 \\
\hline 1986 & 5360 & 40470 & 2950 & 2950 & 37520 & 12830 & 24690 \\
\hline 1987 & 7280 & 47750 & 3630 & 6580 & 41170 & 12830 & 28340 \\
\hline 1988 & 3200 & 55950 & 4240 & 10820 & 45130 & 12830 & 32300 \\
\hline 1989 & 9130 & 65080 & 4900 & 15720 & 49360 & 12830 & 36530 \\
\hline 1990 & 10090 & 75170 & 5560 & 21280 & 53890 & 12830 & 41060 \\
\hline 1991 & & & 8920 & 30200 & & 10270 & \\
\hline 1992 & & & 9850 & 40050 & & 7700 & \\
\hline 1993 & & & 10770 & 50820 & & 5130 & \\
\hline 1994 & & & 11700 & 62520 & & 2560 & \\
\hline 1995* & & & 9260 & 71780 & & 0 & \\
\hline
\end{tabular}

Indicated yeàr denotes perioc ending middle of that year, i.e., $1985=$ mid $1984-$ mid 1985

*Repository operates $3 / 4$ of year 1995, to March 1995.

**Assumed to be stored at some location other than the reactor site pools, for the purposes of this study.

Based on figures from Blomeke \& Kee Tables. (Projections of Wastes to be Generated, International Symposium on the Management of Wastes from the IWR Fuel Cycle, Denver, Colorado, July 11-16, 1976.) 
PRODUCTION AND STORAGE

\begin{tabular}{|c|c|c|c|c|c|}
\hline \multirow[b]{3}{*}{ Year } & \multicolumn{2}{|c|}{ Waste Output } & \multicolumn{2}{|c|}{ Placed in Repository } & \multirow{3}{*}{ Backlog } \\
\hline & Drums & & Drums & & \\
\hline & Per Year & Accumulated & Per Year & Accumulated & \\
\hline 1983 & 480 & 480 & 0 & 0 & 480 \\
\hline 1984 & 1440 & 1920 & 0 & 0 & 1920 \\
\hline 1985 & 2440 & 4360 & 0 & 0 & 4360 \\
\hline 1986 & 13900 & 18260 & 18260 & 18260 & 0 \\
\hline 1987 & 22100 & 40360 & 22100 & 40360 & 0 \\
\hline 1988 & 29800 & 70160 & 29800 & 70160 & 0 \\
\hline 1989 & 16800 & 86960 & 16800 & 86960 & 0 \\
\hline 1990 & 18300 & 105260 & 18300 & 105260 & 0 \\
\hline 1991 & 20200 & 125460 & 20200 & 125460 & 0 \\
\hline 1992 & 22600 & 148060 & 22600 & 148060 & 0 \\
\hline 1993 & 22600 & 170660 & 22600 & 170660 & 0 \\
\hline 1994 & 24500 & 195160 & 24500 & 195160 & 0 \\
\hline $1995 *$ & 18290 & 213450 & 18290 & 213450 & 0 \\
\hline
\end{tabular}

Based on flgures from Blomeke \& Kee Tables. (Projections of Wastes to be Generated, International Symposium on the Management of Wastes from the LWR Fuel Cycle, Denver, Colorado, July 11-16, 1976.) One drum contains .21m3 of material.

Indicated year denotes period ending middle of that year, ie.: $1985=$ mid 1984 - mid 1985

*Repository operates $3 / 4$ of year 1995, to March 1995. 
Table A-5

STORAGE SCHEDULE BY ROOMS

\begin{tabular}{|c|c|c|c|c|c|c|c|c|}
\hline \multirow[b]{2}{*}{ Year } & \multicolumn{4}{|c|}{ PWR } & \multicolumn{4}{|c|}{ BWR } \\
\hline & $\begin{array}{c}\text { \#Canisters } \\
\text { (annuai) }\end{array}$ & $\begin{array}{l}\text { \#Canisters } \\
\text { (accumulated) }\end{array}$ & $\begin{array}{c}\text { \#Rooms } \\
*\end{array}$ & Pane1 & $\begin{array}{c}\text { \#Canisters } \\
\text { (annual) }\end{array}$ & $\begin{array}{l}\text { \#Canisters } \\
\text { (accumulated) }\end{array}$ & $\begin{array}{c}\text { \#Rooms } \\
*\end{array}$ & Panel \\
\hline $\begin{array}{l}1986 \\
1987 \\
1988 \\
1989 \\
1990 \\
1991 \\
1992 \\
1993 \\
1994 \\
1995 * \text { * }\end{array}$ & $\begin{array}{l}2440 \\
3000 \\
3500 \\
4050 \\
4600 \\
7060 \\
7840 \\
8610 \\
9360 \\
7450\end{array}$ & $\begin{array}{r}2440 \\
5440 \\
8940 \\
12990 \\
17590 \\
24650 \\
32490 \\
41100 \\
50460 \\
57910\end{array}$ & $\begin{array}{r}40 \\
88 \\
145 \\
210 \\
284 \\
398 \\
525 \\
663 \\
814 \\
934\end{array}$ & $\begin{array}{c}1,2 \\
3 \\
4,5 \\
6,7 \\
8 \\
9,10,11 \\
12,13 \\
14,15,16 \\
17,18,19 \\
20,21\end{array}$ & $\begin{array}{r}2950 \\
3630 \\
4240 \\
4900 \\
5560 \\
8920 \\
9850 \\
10770 \\
11700 \\
9260\end{array}$ & $\begin{array}{r}2950 \\
6580 \\
10820 \\
15720 \\
21280 \\
30200 \\
40050 \\
50820 \\
62520 \\
71780\end{array}$ & $\begin{array}{r}16 \\
35 \\
57 \\
82 \\
111 \\
158 \\
209 \\
265 \\
326 \\
374\end{array}$ & $\begin{array}{c}1 \\
2 \\
3,4 \\
5 \\
- \\
6 \\
7 \\
8 \\
9 \\
10\end{array}$ \\
\hline
\end{tabular}

* 62 Canisters per room - PWR

192 Canisters fier room - BWR

**. to March 1995 


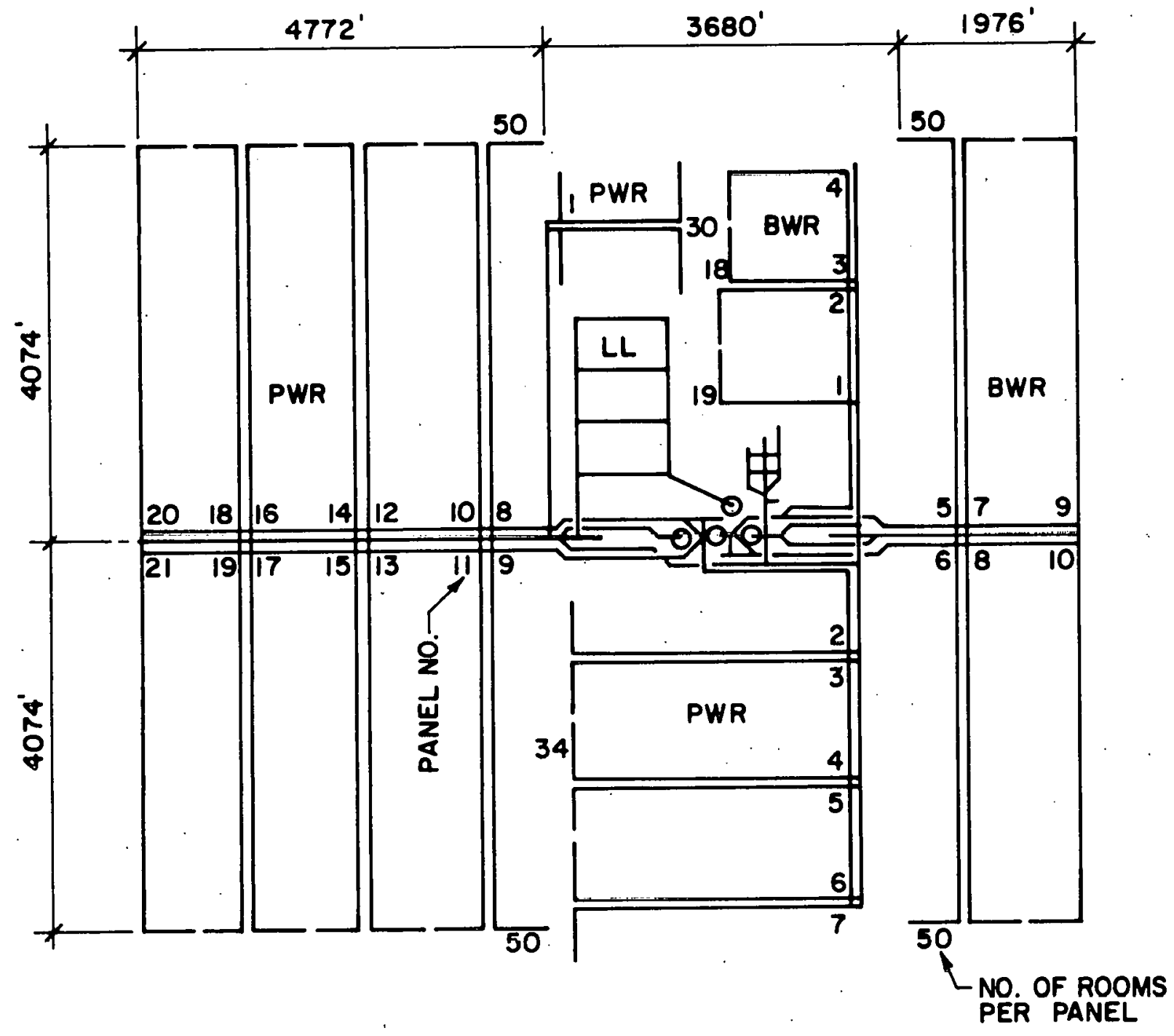

GENERAL PLAN

FIG. NO. A-6 


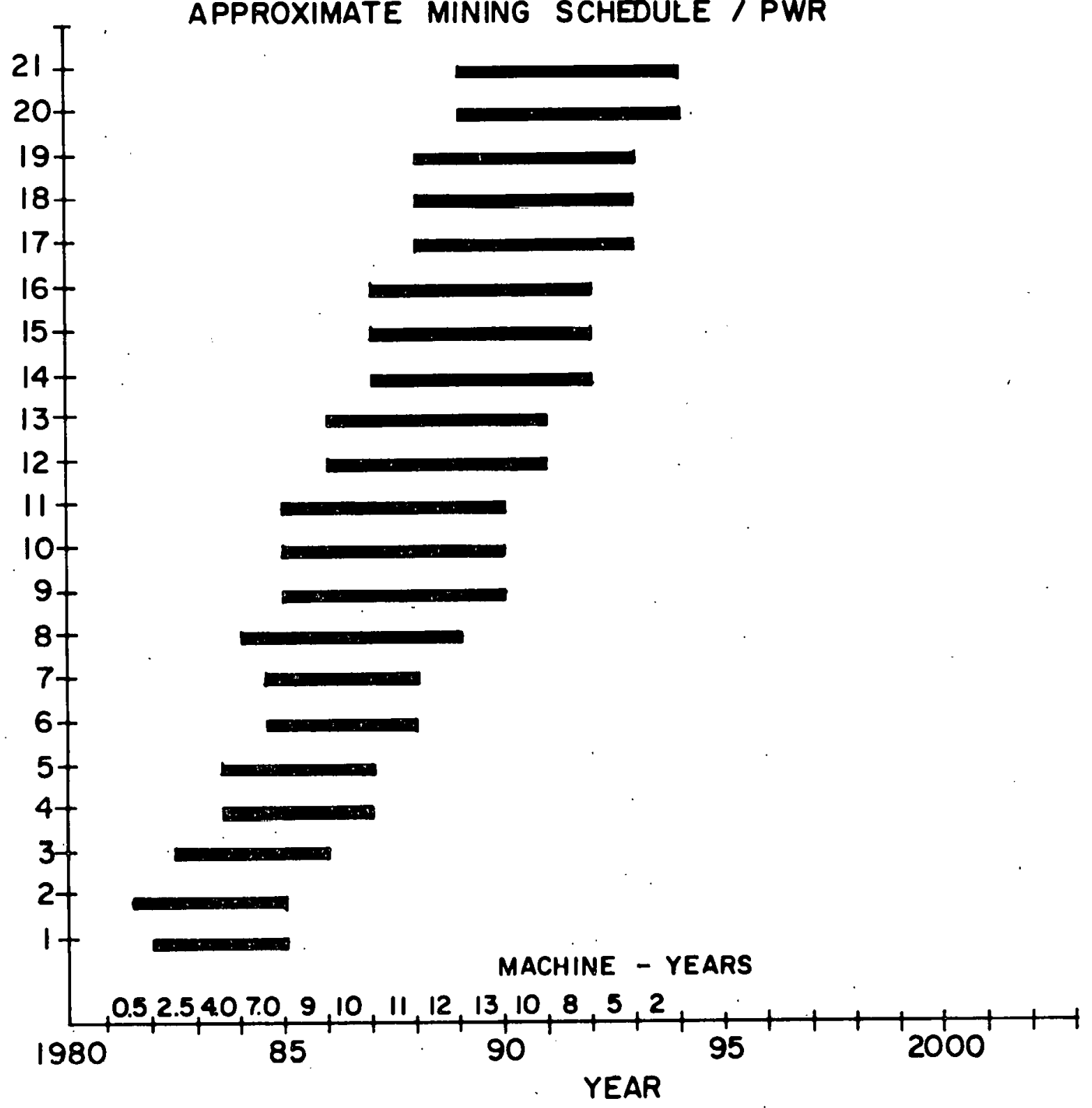

FIG. NO. A-7 
APPROXIMATE MINING SCHEDULE/BWR

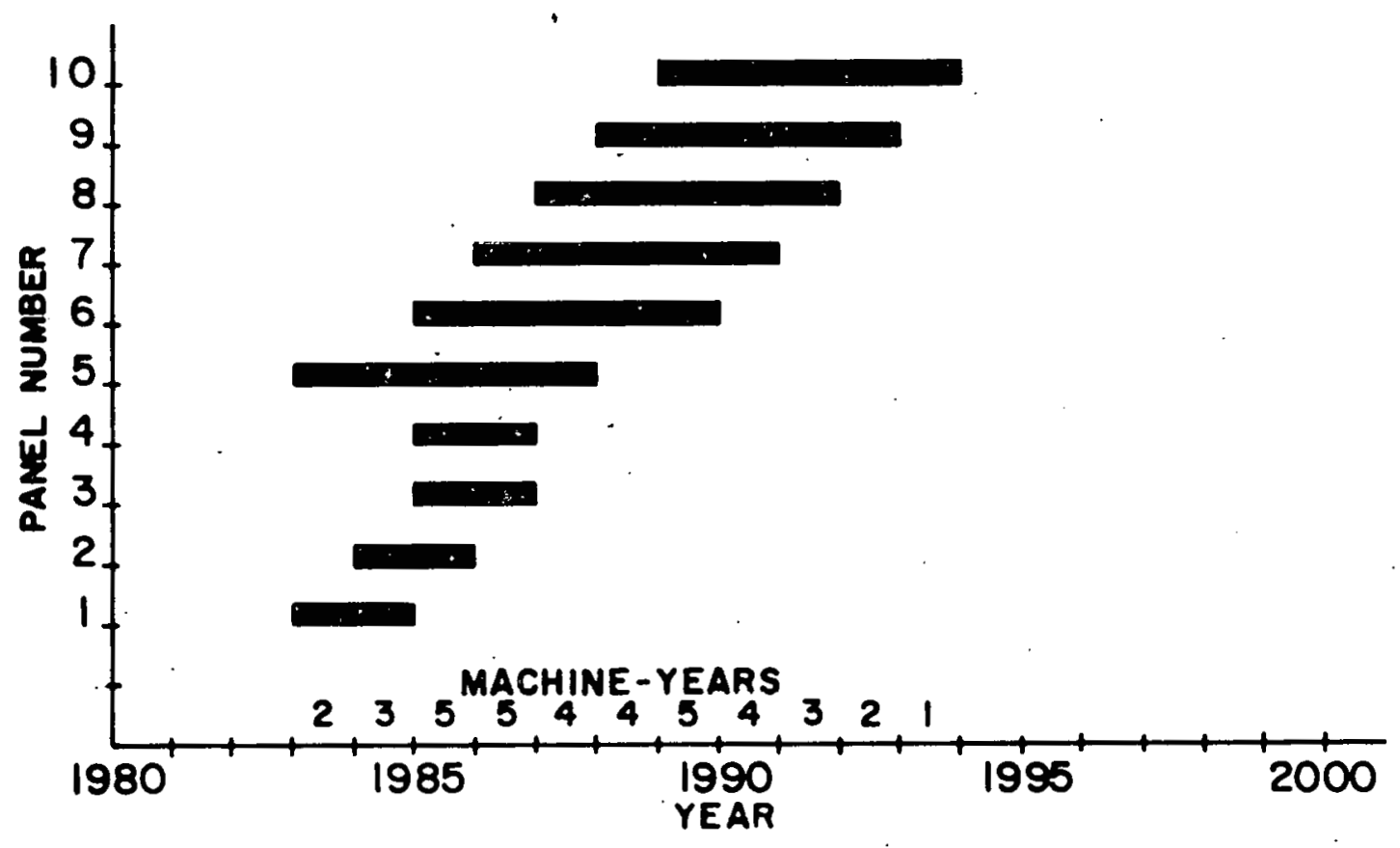

FIG. NO. A-B 


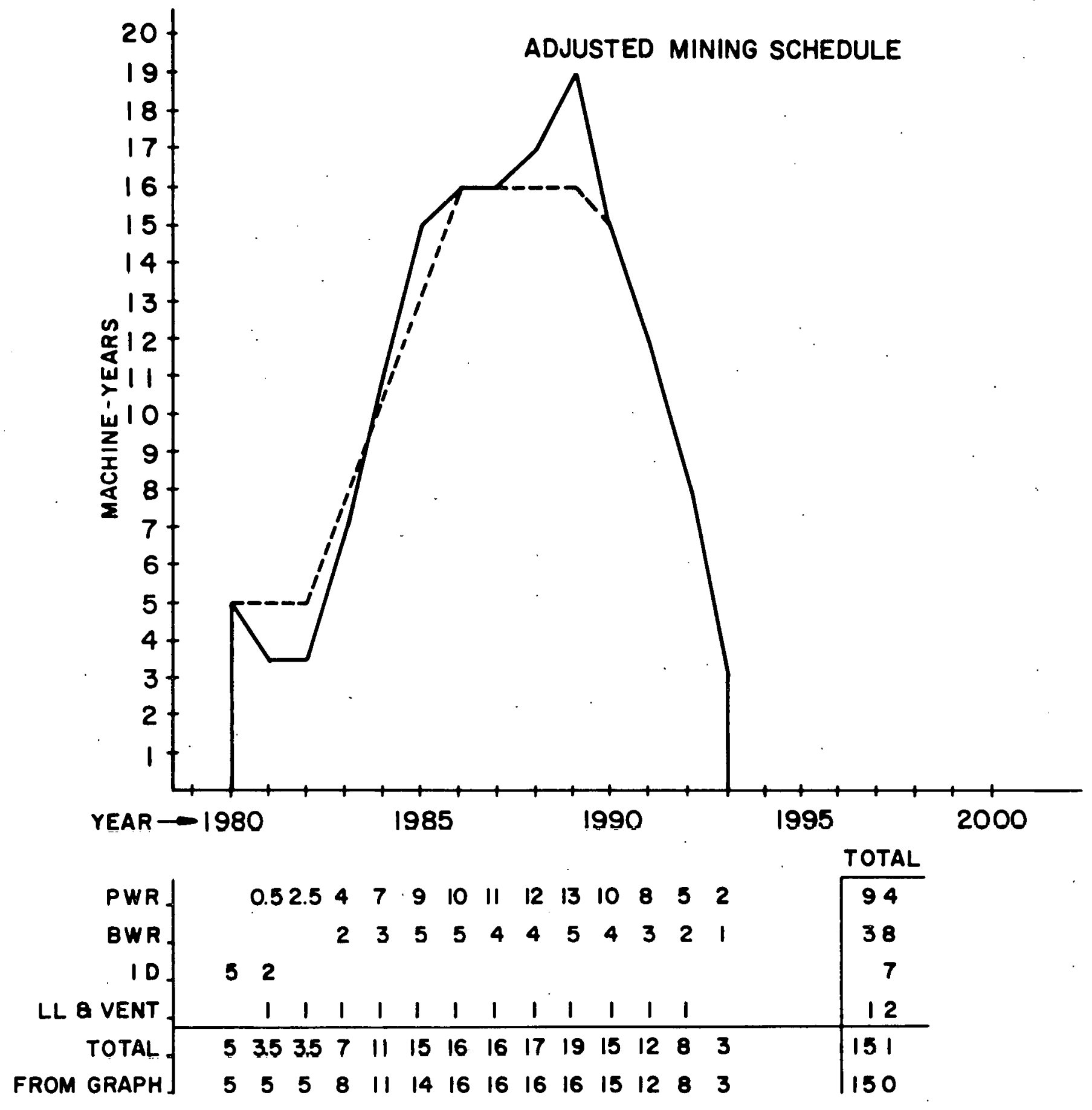

FIG. NO: A-9 
A-9 (Continued)

Aniual Mining Rates

Year

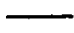

1980

1981

1982

1983

1984

1985

1986

1987

1988

1989

1990

1991

1992

1993
Mining Machines

$x$ Years

$\begin{array}{r}5 \\ 5 \\ 5 \\ 8 \\ 11 \\ 14 \\ 16 \\ 16 \\ 16 \\ 16 \\ 15 \\ 12 \\ 8 \\ 3 \\ \hline 150\end{array}$

Mining Schedule Material Mined (Tons $\times 10^{6}$ )

1.3) Includes initial

1.7) Development

2.0

3.2

4.4

5.6

6.4

6.4

6.4

6.4

6.0

4.8

3.2

$\frac{1.2}{59.0}$

Summary - Material Mined

$\begin{aligned} \text { PWR } & =37.8 \times 10^{6} \text { Tons } \\ \text { BWR } & =15.4 \\ L L & =1.0 \\ \text { Initial Devel. } & =1.8 \\ \text { Ventilation } & =\frac{3.0}{59.0} \times 10^{6} \text { Tons }\end{aligned}$


Figure A-10

SUMMARY

APPROXIMATE

PROJECTIONS OF LWR SPENT FUEL

PRODUCTION AND STORAGE

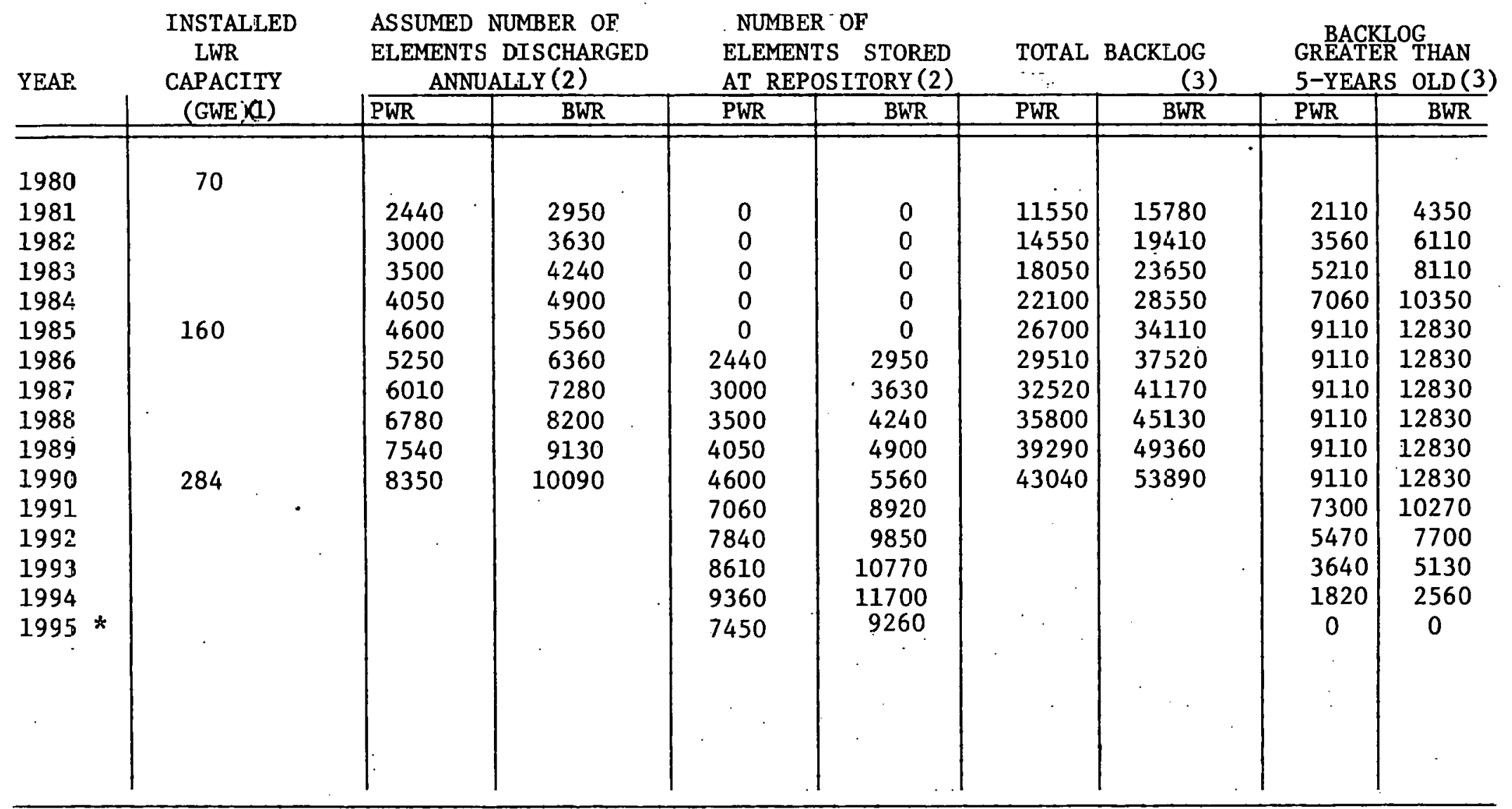

* to March 1995

(1) Figure corresponds to indicated calendar year.

(2) Figure corresponds to period ending middle of indicated year; e.g. 1986=mid 1985 to mid 1986.

(3) Figure corresponds to middle of indicated year. 
APPENDIX B

Mine Operations

Figures

B-1 Estimated Mine Personnel Required

B-2 Estimate of Transporters and Operating Personnel Required: Sub Surface Operations

B-3 Estimated Personnel for Waste Handling 
Appendix B

Mine Operations

\section{Mining Units}

Conventional drilling and blasting will not be employed for mining operations in the storage areas because of possible blasting damage to the facility. Other mining constraints include room height, $(25$ feet in PWR and BWR, and 18 feet in low level areas), room length, 560 feet; and room width, 36 feet in BWR and PWR areas and 38 feet in the low level storage areas. This design results in pillar thickness of 42 feet in the PWR \& BWR areas, and 40 feet in the LL areas.

Conventional mining methods are usually selected for mining in thick salt deposits for reasons of cost and productivity. (Salt is abrasive to continuous mining units and therefore maintenance costs are high.) Continuous mining units have not yet been developed that can mine to a full height of 25 feet in one pass. Some consideration has been given to using continuous mining machines in conjunction with conventional mining.

The mining operations will be performed using electrically powered continuous mining units that cut an opening 12 feet high by 19 feet wide. If the mining machine cuts a second pass beside an initial entry, a room with dimensions 12 feet high by 36 feet wide would be created. If two passes are made later in the floor, the room produced would have dimensions of 24 by 36 feet.

It is assumed that the manufacturer could modify the machine's design sufficiently to permit extra cutting height and a final room height of 25 feet. The slightly larger machine could produce rooms with a width of 38 feet for low level storage and widths of 36 and 30 feet for other areas of the repository if the second pass cutting is adjusted to produce these widths.

\section{Underground Salt Transportation Equipment}

Extensible conveyor systems that receive the mined salt directly behind the mining machine and transport the material without secondary handling, are strongly preferred in many mining applications because of high productivity and luw uperating cost. I lowever, the constraints on mine geometry are such that the loader and truck method, which is more flexible, may be selected for this mining operation. Normally, two trucks operate behind one mining unit, but of ten in restricted areas only one truck can operate efficiently. On very long hauls three or more trucks may be used. 
Electrically-operated trucks could be used in rooms, but the haulage distances are fairly long for trailing cables, and trolley wire systems are not practical for continuous mining systems. Therefore diesel trucks would likely be chosen during a detailed mine planning study.

Trucks will transport the mined salt to branch corridor conveyors which will be frequently extended so that truck haulage distances are maintained as short as possible. Branch corridor conveyors will transfer the salt to roof-suspended main line conveyor systems that transport the salt to a 10,000-ton underground storage bin. A reclaim conveyor beneath the storage bins is fed by vibratory feeders that are automatically controlled. The salt is held in a surge bin prior to being conveyed to loading pockets for hoisting to surface.

The main conveyor from the low level storage area feeds the BWR main conveyor through an ore pass (chute) that is drilled through the salt and lined with welded steel ring segments. The conveyors to the low level and BWR/PWR areas will be 36 inches and 48 inches wide repsectively. In the BWR/PWR main line, the conveyor nearest to the storage bins will be 54 inches wide and the second conveyor will be 48 inches wide.

Many vehicles will be required for the transportation of men and materials throughout the mine. In addition, graders, portable cranes and front-end loaders will also be used. The cuttings produced during augering of the storage holes will likely be handled by front-end loaders or large scooptrams. The drilling of 24-inch holes in the floor for storage will be a major operation.

\section{Underground Support Facilities}

Support facilities for mining operations will be located between the PWR and the BWR mine areas. Access to all mining areas is provided from the central service area, which would include a communications center, a warehouse and large mechanical and electrical shops, a parking area, a tool room, and a communication center. This location is most suitable to provide efficient service for all mine areas and will have the least heat effect from storage areas.

\section{Production Capability of the Continuous Mining Units}

The use of trucks for salt handling and the restricted mining geometry may result in a production rate of 400,000 tons per year for the mining machines in the storage rooms. This rate assumes 600 operating shifts per year and 670 tons per shift. The number of mining units required over the excavation period for the facility are given in Figure A9 in Appendix A. It will be noted from this table that one or more mining units are required as spares so that major overhauls can be routinely performed on each machine in turn. It is probable that three or more mining units would be replaced because of wearout or obsolescence in the first ten years. Trucks require overhauls and suffer frequent breakdown. Each operating mining unit would therefore require about 2.7 trucks. An estimate of the total mine-related manpowers is given in Table B-1. 


\section{Waste Transporters}

It has been determined that even at the peak receiving rate, the surface facility is adequate to handle the incoming waste cans. These cans also must be properly received at the mine level, transported to the appropriate storage room, and stored at the peak rate. Accordingly, an estimate has been made of the number of transporters required during the peak year as well as at five year intervals starting with 1985.

To make this estimate, the average speed of the vehicle was taken as 2.5 mph. There is necessarily an element of uncertainty as to the actual running speed of the vehicle since it has yet to be developed; it may in fact be as high as $5 \mathrm{mph}$. The $2.5 \mathrm{mph}$ figure was introduced to include an allowance for delays due to turning, brief breakdowns, etc. For each year, the approximate location of storage for the waste units was determined and the distance from the shaft to this point was found. Using this distance and the average speed of $2.5 \mathrm{mph}$, the time required for the transporter to travel from the shaft to the storage hole was determined; the total cycle time was taken as twice this time plus 30 minutes which accounts for receiving and depositing of the waste can. This cycle time was used to calculate the number of transporters required assuming 6.5 work hours per shift, 3 shifts/day and 250 working days/year.

As shown in Figure B2, during the peak year, 15 vehicles would be required for the total placement operations. Additional vehicles would be needed as backups. In a final design, the underground storage procedure would have to be analyzed in detail using queuing theory to ensure that the number of vehicles could be accommodated. The estimated operating personnel for waste handling are given in Table B-3.

\section{Surface Facilities}

Elaborate surface installations would be required for an underground mining operation of the size contemplated. Some of the facilities may be integrated with those that are required to support the surface operations for the handling of waste materials.

Buildings should be provided for the following: warehousing, utilities, maintenenace, services, salt storage loadout and shipping. About 90 staff persons associated with mining operations would require office space. For underground and shaft personnel, the facilities would include safety and training areas, changing rooms with individual lockers, showers and laundry areas, a lamp room, and an area for assignment of work. A briefing room and separate changing rooms may be provided for visitors to the facility.

Mining related personnel may be grouped into the following categories: management, engineering, administration, services and supervision. The office 
requirements for some groups may be quite large. For example, the administration group might include accounting, purchasing, warehouse, personnel, computer, telex, traffic controller for shipments, public relations, security and safety. General office spaces normally provide for conferences, lunchrooms, etc.

Provisions for mining-related utilities may include electrical sub-stations, fuel handling and emergency power stations. The building housing maintenance facilities would not be large because of the proposed shop area underground. An ore bin and conveyor gallery to the storage area would be required as would parking areas and garages. Tunnels or galleys between buildings may be required if the facility is located in cold portion of the country. 
Table B-1

ESTIMATED MINE PERSONNEL REQUIRED FOR TYPICAL MINES

Typical Efficient Mining Rates

(X106 Annual Tons)

$\underline{2.5} \quad \underline{3.6} \quad \underline{5.7} \quad \underline{10.8} \quad \underline{6.4}$ (Interpolated)

I. Mine Operating and Construction

1. Supervision and Engineering

2. Hourly Employees

15

19

$19 \quad 23$

29

24

$\begin{array}{lllll}69 & 97 & 118 & 187 & 128\end{array}$

II. Mine Maintenance

1. Maintenance Supervisors

2. Hourly Paid Employees

$\begin{array}{rrrrr}16 & 14 & 15 & 17 & 15 \\ 65 & 81 & 98 & 128 & 102\end{array}$

III. Administration

$\begin{array}{lllll}30 & 37 & 43 & 52 & 44\end{array}$

IV. Surface MaIntenance

30

37

49

$65 \quad 51$

V. Project Engineering

$\begin{array}{lllll}3 & 3 & 5 & 8 & 6\end{array}$

Total

$\underline{228}$

$\underline{288}$

$\underline{351} \quad \underline{486}$

$\underline{370}$

Estimated total employment for mine with 6.4 X.106 annual tons approximately 370 men. 
Table B-I (Continued)

\section{Mine Manpower Requirements for Typical $2.5 \times 10^{6}$ Annual Tonnage Mine}

(efficient operation)

I. Mine Operating and Construction

1. Supervision and Engineering

Mine Superintendent

Mine Production Foreman

Senior Shift Supervisors

Junior Shift Supervisors

Instructor

Spare Supervisor

Construction Supervisor

Chief Mine Engineer

Chief Surveyor

Junior Mine Engineer

\begin{tabular}{|c|c|}
\hline $\begin{array}{l}2,500,000 \\
\text { Tons/Year }\end{array}$ & $\begin{array}{l}6,400,000 \\
\text { Tons/Year (estimated) }\end{array}$ \\
\hline 1 & 1 \\
\hline 1 & 2 \\
\hline 4 & 6 \\
\hline 4 & 6 \\
\hline 1 & 2 \\
\hline 1 & 2 \\
\hline - & - \\
\hline 1 & 1 \\
\hline 1 & 2 \\
\hline$\frac{1}{15}$ & $\frac{2}{21}$ \\
\hline
\end{tabular}

2. Hourly Paid Employees

Borer Operators

$\begin{array}{crr} & 12 & 23 \\ & 26 & 51 \\ & 6 & 10 \\ & 1 & 2 \\ & 2 & 4 \\ & 4 & 8 \\ & 4 & 8 \\ & 2 & 3 \\ & 2 & 3 \\ & 1 & 2 \\ & 1 & 1 \\ & 2 & 2 \\ \text { Absentees (8\%) } & 1 & 2 \\ & 64 & 119 \\ & 59 & 9 \\ & 69 & 128\end{array}$

Other Operators

Belt Reclaiming

Ventilation

Clean-up, flonor cutting

Mtce. u/g openings

Crusher Operators

Cage tenders

Surveyors

Technician

Clerk

Drymen

Safety and Lamp Man 
Table B-1 (Continued)

\section{$\underline{2.5} \quad \underline{6.4}$}

II. Mine Maintenance

1. Maintenance Supervision

Mine Mtce. Super.

Mine Mtce. Foreman

Mtce. Shift Supervisor

Major Overhaul Supervisor

Supervisor Truck Repair

Supervisor, Conveyors, Crusher

Supervisor Belt Extensives

Supervisor Main Workshop

Warehouse Supervisor

Electrical Supervisor

Mechanical Engineer

Mtce. Planner

\begin{tabular}{cc}
1 & 1 \\
1 & 1 \\
4 & 3 \\
1 & 1 \\
1 & 1 \\
1 & 1 \\
1 & 1 \\
1 & 1 \\
1 & 1 \\
2 & 2 \\
1 & 1 \\
1 & 1 \\
\hline 16 & 15
\end{tabular}

2. Hourly Paid Employees

Hoistmen

Warehousemen

Shaft Mechanics

Shift Mechanics

Preventive Mtce.

Major Overhaul

Equipment Repair.

Belt movements etc.

Repair Conveyors

Machinist

Shift Electricians

Equipment Electricians

Helpcrs

Clerk

\begin{tabular}{rrr} 
& 4 & 6 \\
& 4 & 6 \\
2 & 3 \\
8 & 12 \\
& 5 & 8 \\
5 & 8 \\
5 & 8 \\
& 10 & 16 \\
4 & 6 \\
& 1 & 2 \\
& 4 & 6 \\
& 5 & 8 \\
& 2 & 3 \\
Sub & 1 & 2 \\
60 & 94 \\
Absentees (8\%) & 5 & 8 \\
\cline { 2 - 2 } & 65 & 102
\end{tabular}


Table B-2

\section{ESTIMATE OF TRANSPORTERS AND OPERATING PERSONNEL REQUIRED: SUB-SURFACE OPERATIONS}

Assumptions: $2.5 \mathrm{mph}$ average speed 250 working days/year

3 shifts/day

$6.5 \mathrm{hrs} / \mathrm{shift}$

$0.5 \mathrm{hr}$. to receive and bury can

PWR

\begin{tabular}{|c|c|c|c|c|c|}
\hline Year & $\begin{array}{l}\text { Canisters } \\
\text { Per Day } \\
\end{array}$ & $\begin{array}{l}\text { Maximum 1-Way } \\
\text { Distance (ft) }\end{array}$ & Cycle Time (hr) & $\begin{array}{l}\text { Number of } \\
\text { Transporters }\end{array}$ & Personnel \\
\hline 1985 & 10 & 4500 & 1.2 & 1 & 30 \\
\hline 1990 & 18 & 6000 & 1.4 & 2 & 36 \\
\hline 1991 & 28 & 8000 & 1.7 & 3 & 43 \\
\hline 1995 & 41 & 9000 & 1.9 & 4 & 50 \\
\hline
\end{tabular}

BWR

\begin{tabular}{|c|c|c|c|c|c|}
\hline Year & $\begin{array}{c}\text { Canisters } \\
\text { Per Day } \\
\end{array}$ & $\begin{array}{l}\text { Maximum 1-Way } \\
\text { Distance (ft) }\end{array}$ & Cycle Time (hr) & $\begin{array}{l}\text { Number of } \\
\text { Transporters } \\
\end{array}$ & Personnel \\
\hline 1985 & 12 & 4500 & 1.2 & 1 & 30 \\
\hline 1990 & 22 & 6500 & 1.5. & 2 & 36 \\
\hline 1991 & 36 & 6500 & 1.5 & 3 & 43 \\
\hline 1995 & 51 & 8000 & 1.7 & 5 & 56 \\
\hline
\end{tabular}

TOTAL PWR/BWR

Transporters

Year in Operation

1985

1990

1991

1995

\section{2}

4

6

9
Total

Spares Transporters

4

6

8

11
Personne1

60

72

86

106

LOW LEVEL

\begin{tabular}{lccccc} 
Year & $\begin{array}{c}\text { Max 1-way } \\
\text { Dist. (ft) }\end{array}$ & $\begin{array}{c}\text { Cycle Time } \\
(\mathrm{hr})\end{array}$ & $\begin{array}{c}\text { Drums } \\
\text { Per Day }\end{array}$ & $\begin{array}{c}\text { Number of } \\
\text { Transporters }\end{array}$ & Personnel \\
\cline { 2 - 5 } & 1400 & 0.7 & 88 & 1 & 33 \\
1987 & 3100 & 1.0 & 100 & 1 & 33
\end{tabular}


TABLE $\quad B-3$

ESTIMATE OF OPERATING

PFRSONNEL REOUIRED FOR WASTE HANDLING

\begin{tabular}{|c|c|c|c|}
\hline & 1985 & 1990 & 1995 \\
\hline Canistered Waste Handling & 17 & 18 & 20 \\
\hline Low Level Waste Handling & 8 & 8 & 10 \\
\hline Maintenance \& Operations Support & 32 & 42 & 48 \\
\hline $\begin{array}{l}\text { General Administration } \& \\
\text { Technical Support }\end{array}$ & 30 & 32 & 35 \\
\hline Sub Surface Waste Handling & 93 & 105 & 135 \\
\hline Total & 180 & 205 & 252 \\
\hline
\end{tabular}


APPENDIX C

Shaft Construction Information 
Appendix C

Shaft Construction Information

Upon completion of the five facility shafts, preparations for a permanent head frame for the two M\&M shafts will begin. The shell of the permanent headframe for the two M\&M shafts. (150 feet above ground) will be slip-formed during the drilling of the Canistered Waste Shaft. This shell will be bulkheaded approximately ninety feet above ground so that this lower portion of the M\&M headframe can serve as a construction headframe. The upper portion of the headframe can be completed and the permanent tower mounted hoists installed in the headframe while each M\&M shaft is being sunk, lined and equipped from the surface to the shaft bottom. Sinking sequence of each M\&M shaft, the enlargement of the 7 foot diameter hole to 28 foot diameter hole, will be accomplished by advancing the bottom fifteen feet on one shift, forming and pouring 15 feet of concrete liner on the second shift and equipping 15 feet on the third shift.

The bottom portion of the sinking will be advanced using a four or five boom shaft drill jumbo drilling approximately forty six holes of 2 inch diameter around the 7 foot diameter bored pilot raise. This will be done by blasting. The other al ternative in place of blasting is to use two boom "rock buster" jumbo. Each boom will carry a remote controlled Ho-Ram rockbreaker similar in appearance and function to a pavement breaker but about five times as large in physical dimensions. This rockbreaker will deliver up to one-half million foot-pounds of impact energy per minute and incorporate an integral muffler to meet O.S.H.A. noise level requirements.

The shaft jumbo will be carried on a four deck Galloway stage. The stage will be controlled by winches on surface. The stage will also carry a $1 / 3$ cubic yard Cryderman mucker (used to facilitate cleaning the rock face after a blast). This will bring the total suspended weight of the stage to about 35 tons.

In order to align the shaft structural steel from plumb lines fixed top and bottom in the M\&M shaft, the excavation and concrete lining will be carrled out 300 feet ahead of the equipping of the shaft with steel sets and guides and permanent service lines. The shaft steel will be installed from a single deck platform suspended by chain hoists or winches and safety slings from the previously installed steel. Upon completion of the sinking the stage will be cut up and removed and all sinking gear removed from the shaft. At this time the permanent hoists will be roped up and permanent shaft conveyances installed.

Once the M\&M shaft is installed the rock hoisting function of the Canistered Waste Shaft is no longer required. The Canistered Waste Shaft will then be lined with concrete using a small multi-deck stage to handle the formwork. The concrete for this lining will travel down the shaft in a carefully plumbed six inch diameter slick line. The loading pocket will be installed when the shaft reaches bottom elevation. 


\section{General}

A total of six hoists will operate in the four of the five shafts. Two will be ground mounted drum hoists and four hoists will be tower mounted friction (Koepe) hoists.

The drum hoists will be situated on concrete foundations in separate hoist houses on the surface, one each for the Canistered Waste Shaft and the LLW Shaft. The two Koepe hoists will be mounted approximately 140 feet above ground level directly over each men and material shaft in a lower headframe.

All hoists will be driven by direct current motors. All AC/DC conversion equipment will be fully solid state (Thyristor variflux). The electric supply network will be protected from Thyristor generated harmonic currents and voltage drops. All hoists will have disc brakes, spring applied and hydraulic released. All hoists and hoist ropes are designed to conform to the strictest factors of safety in North America.

The hoist drum shafts are forged steel ASTM No. A235-55, Class 'E' normalized and stress relieved; the drum barrels are fully annealed cast steel B.S. 592, grade B; the drum spiders are fully annealed cast steel B.S. 592, Grade C; and the drum bolts are EN. 8 (normalized).

\section{The LLW Shaft}

The LLW shaft hoisting system is designed to handle low level pallets of maximum size 4 feet $\times 6$ feet $\times 6$ feet, 6 inches high and maximum weight of five tons.

The LLW shaft hoist will be a ground mounted single drum type, with a speed of 1200 FPM and a capacity (static rope pull) of 21,620 lbs. The brakes will be as per general specification, and the emergency brakes will be weight applied, manual released, raliper hrakes on a pinion shaft. The hoist controller will be a model ' $C$ ' Lilly control single governor, which will provide protection from overspeed, overwind, and failure to decelerate at a given rate approaching destination. Hoisting ropes will be $6 \times 33$ flattened strand best standard grade catalogued with a breaking strength of 77.5 tons.

\section{Canistered Waste Shaft}

The canister shaft hoisting system is designed to handle canisters of PWR and BWR spent fuel having a maximum size of 15 inches diameter $\times 16$ feet long and a maximum weight of $10,000 \mathrm{lbs}$. Total suspended weight including canister 
shaft cage and cross head is estimated 15,500 be 8100 lbs. It will use a ground mounted single drum, with a speed of 1000 FPM and a capacity (static rope pull) of 22,000 lbs. The drums will be 9 feet in diameter, parallel grooved for wire $13 / 8^{\prime \prime}$ rope.

The prime mover will be a 600 RMS HP DC drive. The brakes, emergency brakes, and hoist controller will be the same as for the LLW system. The ropes would be $6 \times 16 / 6 \times 7$ steel core non-rotating best standard grade catalogued with a breaking strength of 71 tons.

\section{Men and Material Shafts}

For these shafts, friction type (Koepe) hoists are preferred over drum hoists because the capital and operating costs will be less at the hoisting depth and capacities required. Both hoists will run at 2000 feet per minute, which is the most economical speed at this depth of hoisting.

The cage hoists are designed with separate criteria:

- Capacity to sling 26 ton gear box (heaviest piece) of mechanical miner with cage removed from cage bridle.

- Capacity to raise and lower diesel powered service vehicles in the cage.

- The cage hoist will have the capacity to hoist up to 70 men in one trip.

The cages will use identical tower mounted friction hoists both with a speed of 2000 feet per minute. The drum wheels are 10'-6" in diameter, with four rope treads @ 12" o.c. grooved for a 1 1/4" diameter wire rope. The prime movers will be 1000 RMS HP DC drives for both. As for all hoists, disc brakes are used since when compared to the conventional caliper brake, they have a smoother effort, are of lower inertia and are not subject to self energizing. The cage (and skip) hoists will feature four disc brakes, two on each hoist flange. Each brake is operated independently so that failure of one brake will still leave $75 \%$ of the maximum breaking effort. Braking effort under the various operations is controlled by a master set of reducing valves in the hoist console. Each brake will produce a braking effort determined solely by pilot pressure, irrespective of brake shoe wear. No emergency brakes are required. The four independent brakes described above together with hoist governor safeties are sufficient. The hoist controller is a model ' $C$ ' Lilly controller $\mathrm{c} / \mathrm{w}$ duplex governor and standard dial. The hoist ropes will be galvanized for protection from salt atmosphere, and will be of fully locked coil construction for two reasons: 1) the rope dressing required is a light oil, lightly applied instead of a heavy grease applied liberally (the major lubrication for a locked coil is internal, and 2) the percentage of rope area bearing on the rope groove tread is $84 \%$ for fully locked coil construction compared with $47 \%$ for flattened strand and $29 \%$ for round strand. The hoist analysis requires $11 / 4^{\prime \prime}$ diameter head ropes. The tail ropes will be of non-rotating round strand construction equal in total weight to the headropes. 


\section{Skip Hoists}

These are tower mounted friction type hoists both with speeds of 2000 feet per minute. The PWR shaft hoist will hoist two 23 ton capacity skips in balance. Trip time will be 91 seconds and the hoist will be capable of hoisting 15,500 tons per day. The smaller BWR hoist will have the same hoisting cycle, but will require only 12.6 ton capacity skips to hoist 8,500 tons/day.

Skip Hoist Specifications

$\begin{array}{lcccl} & \begin{array}{l}\text { Wheel } \\ \text { Diam }\end{array} & \begin{array}{l}\text { Number } \\ \text { of Ropes }\end{array} & \begin{array}{l}\text { Head Rope } \\ \text { Diam }\end{array} & \begin{array}{l}\text { RMS } \\ \text { HP }\end{array} \\ \text { PWR Hoist } & 1^{\prime}-6^{\prime \prime} & 6 & 11 / 4 & 2900 \\ \text { BWR Hoist } & 9^{\prime}-6^{\prime \prime} & 4 & 11 / 8 & 1600\end{array}$

The hoist brakes will as for the cage hoist. The hoist controls are model 'C' Lilly controls complete with duplex governors and standard dials. 
APPENDIX D

Canister Rupture Analysis 
Appendix D

Analysis Concerning Canister Rupture

Inside the Proposed Waste Insolation Facility

The following accident condition and ventilation parameters are used for this analysis:

\section{A. Accident definition:}

1. A total of 1800 Curies of Krypton-85 is released within a duration of 1 hour.

2. The peak radioactivity will occur during the first air change when $65 \%$ of the total activity is released to the atmosphere.

\section{B. Accident parameters:}

1. The design air change rate is about 6 changes per hour. For the purpose of this analysis, 10 changes per hour will be assumed.

2. The stack is 360 feet.(110 m.) high.

3. There are no buildings or elevated topography to interfere with plume propagation.

The worst case concentration-to-source-strength ratios $(\mathrm{X} / \mathrm{Q})$ on the ground are investigated using the atmosphere dispersion model recommended by the NRC. ${ }^{2}$ dilution factors over a large range of distance.

The worst case is defined by class $\mathrm{F}$ conditions accompanied by fumigation. This case is characterized by a severe inversion above the stacin, with highly unstable conditions between the inversion layer and the ground. These conditions may only occur in the early morning as the atmosphere changes from class $F$ to a less stable condition as a result of strong insolation. Such conditions would normally last less than 30 minu tes for facilities more than 2 miles from any large body of water, however, in very rare instances these conditions have been known to persist for several days.

The worst case $\mathrm{X} / \mathrm{Q}$ ratios along with corresponding worst case meteorological conditions are listed in Table D- 1 for the location of maximum concentration and for the facility boundary. 
Based on these stack exhaust dilution factors, the worst case radio-activities for three different time durations are summarized in Table D-2.

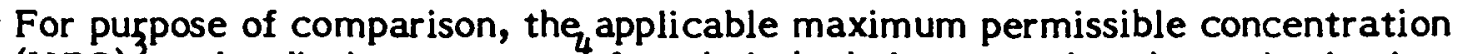
(MPC) $)^{3}$ and radiation exposure ${ }^{4}$ for whole body in unrestricted area is also included in Table D-2.

The worst-case 24-hour average concentration at the boundary is 21 times the MPC level for continuous exposure in an unrestricted area. This allows a safety factor ${ }_{5}$ of about 24 before reaching the 24 -hour accident notification requirement.

All of the above assumptions are extremely conservative and ignore mitigating factors such as mixing and dilution within the facility and the increase in the effective stack height due to the exhaust velocity of gases from the stack. Consideration of these factors along with different wind conditions would give a more probable prediction of concentration and radiation dose.

\section{NOTES}

1. "NWTS Repository - Accidental Volatile Fission Produce Release," Memo from Bob Wilems of SAI, Oak Ridge on March 28, 1977.

2. USAEC Regulatory Guide 1.3, June 1974.

3. 10 CFR 20, Appendix B, Table II.

4. 10 CFR 20.105

5. 10 CFR 20.403(b) (2). 
Table D-1. Worst Case Dilution Factors

\begin{tabular}{|c|c|c|c|c|}
\hline Location & $\begin{array}{l}\text { Meteoorological } \\
\text { Wind Speed,u: } \\
\text { (m/sec) }\end{array}$ & $\begin{array}{l}\text { Conditions } \\
\text { Stability } \\
\text { Class }\end{array}$ & $\begin{array}{l}\text { Distance } \\
\text { from Stack } \\
\text { (meters) } \\
\end{array}$ & $\begin{array}{l}x u / 0 \\
\left(m^{-2}\right)\end{array}$ \\
\hline Maximum Radioactive & 1 & A & 375 & $1.8 \times 10^{-5}$ \\
\hline Concentration & 1 & $F^{b}$ & $.5 .5 \times 10^{4}$. & $1.3 \times 10^{-6}$ \\
\hline Facility Boundary & $\begin{array}{l}1 \\
1 \\
1\end{array}$ & $\begin{array}{l}A^{b} \\
F^{b}\end{array}$ & $\begin{array}{l}400 \\
400 \\
400\end{array}$ & $\begin{array}{c}1.8 \times 10^{-5} \\
4 \times 10^{-56} \\
2.3 \times 10^{-4}\end{array}$ \\
\hline
\end{tabular}

Table D-2. Worst Case Concentration and Radiation Exposure (Based on $1 \mathrm{~m} / \mathrm{sec}$ wind speed)

\begin{tabular}{|c|c|c|c|c|c|c|c|c|}
\hline Time Period & $\begin{array}{l}\text { Total } \mathrm{kr}^{85} \\
\text { Release } \\
\text { (Curies) }\end{array}$ & $\begin{array}{l}\text { Source } \\
\text { Strength } \\
Q(\text { Ci } / \text { sec })\end{array}$ & $\begin{array}{l}\text { Stability } \\
\text { Class }\end{array}$ & $\begin{array}{r}\text { Concentrat } \\
x\left(\mathrm{pC} \mathrm{i} / \mathrm{cm}^{3}\right) \\
\operatorname{Max} \text { Boundary }\end{array}$ & Limite & Total & $\begin{array}{l}\text { Dose } \\
\text { (mrem) } \\
\text { Eoundar }\end{array}$ & $\begin{array}{l}\text { Exposure } \\
\text { ry Limite }\end{array}$ \\
\hline $\begin{array}{l}\text { First Air } \\
\text { Change } \\
(6 \text { min. })\end{array}$ & 1170 & 3.25 & $\begin{array}{l}\mathrm{A} \\
\mathrm{Fb} \\
\mathrm{FC}\end{array}$ & $\begin{array}{lr}58 & 58 \\
4.3 & 0 \\
- & 748\end{array}$ & - & $\begin{array}{l}2.1 \\
.16 \\
-\end{array}$ & $\begin{array}{r}2.1 \\
28\end{array}$ & - \\
\hline $\begin{array}{l}\text { One Hour } \\
\text { Average }\end{array}$ & 1800 & 0.5 & $\begin{array}{l}\mathrm{A} \\
\mathrm{Fb} \\
\mathrm{FC}\end{array}$ & $\begin{array}{ll}9 & 8.9 \\
.66 & 0 \\
-\quad 115\end{array}$ & - & $\begin{array}{l}3.3 \\
.24 \\
-\end{array}$ & $\begin{array}{r}3.3 \\
42\end{array}$ & - \\
\hline $\begin{array}{l}24 \text { Hour } \\
\text { Average }\end{array}$ & 1800 & $0.02: 1$ & $\begin{array}{l}A \\
F b \\
F C\end{array}$ & $\begin{array}{rr}.38 & .37 \\
.03 & 0 \\
- & 4.8\end{array}$ & $\begin{array}{l}.3 \\
.3 \\
.3\end{array}$ & $\begin{array}{l}3.3 \\
.24 \\
-\end{array}$ & $\begin{array}{r}3.3 \\
0 \\
42\end{array}$ & $\begin{array}{l}2 \\
2 \\
2\end{array}$ \\
\hline
\end{tabular}

a For a $360 \mathrm{ft}$ stack.

${ }^{b}$ Stability Class $F$ without fumigation.

CStability Class $F$ with fumigation.

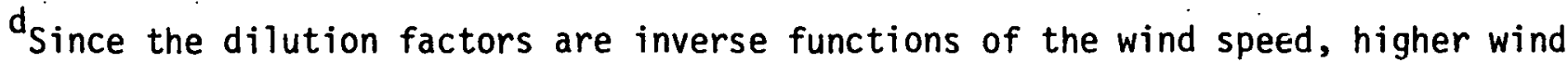
speeds would reduce the concentrations and dose exposures for an accident.

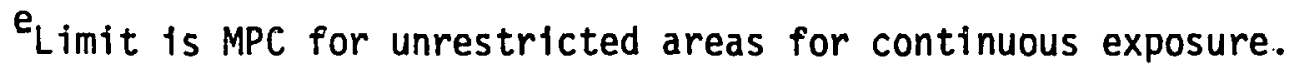




\section{APPENDIX E}

\section{Drawings}

1 Repository Site and Plot Plan

2 Schematic Flow Diagram/Canistered Waste

3 Canistered Waste Receiving Building - Plans and Sections

4 Schematic Flow Diagram/Low Level Waste

5 Low Level Waste Receiving Building - Plan and Sections

6 Mine Master Plan

$7 \quad$ Mine Partial Plan and Sections

8 Shaft Sections and Miscellaneous Details

9 Ventilation Plan

10 Corridor and Room Layout 


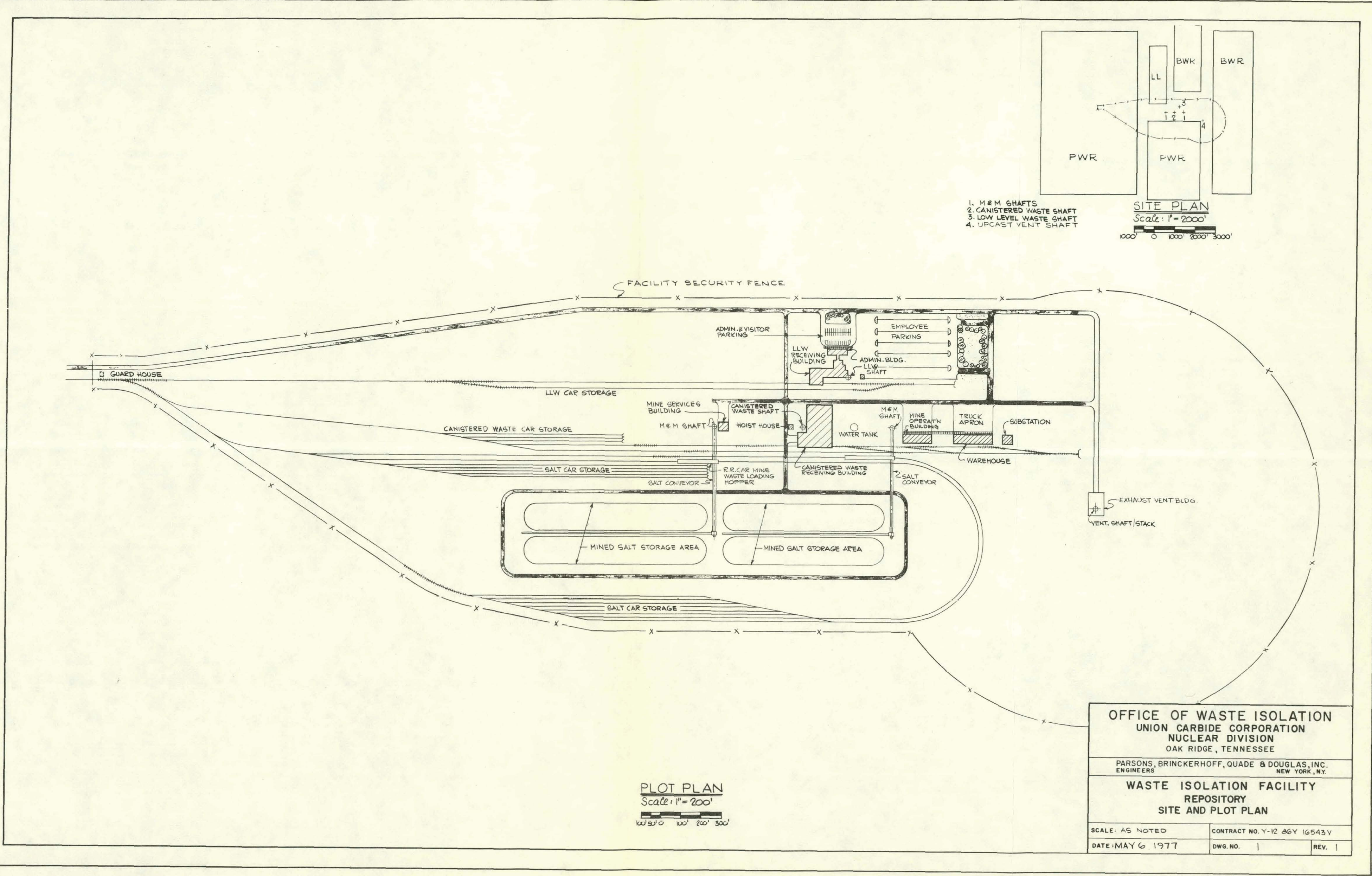




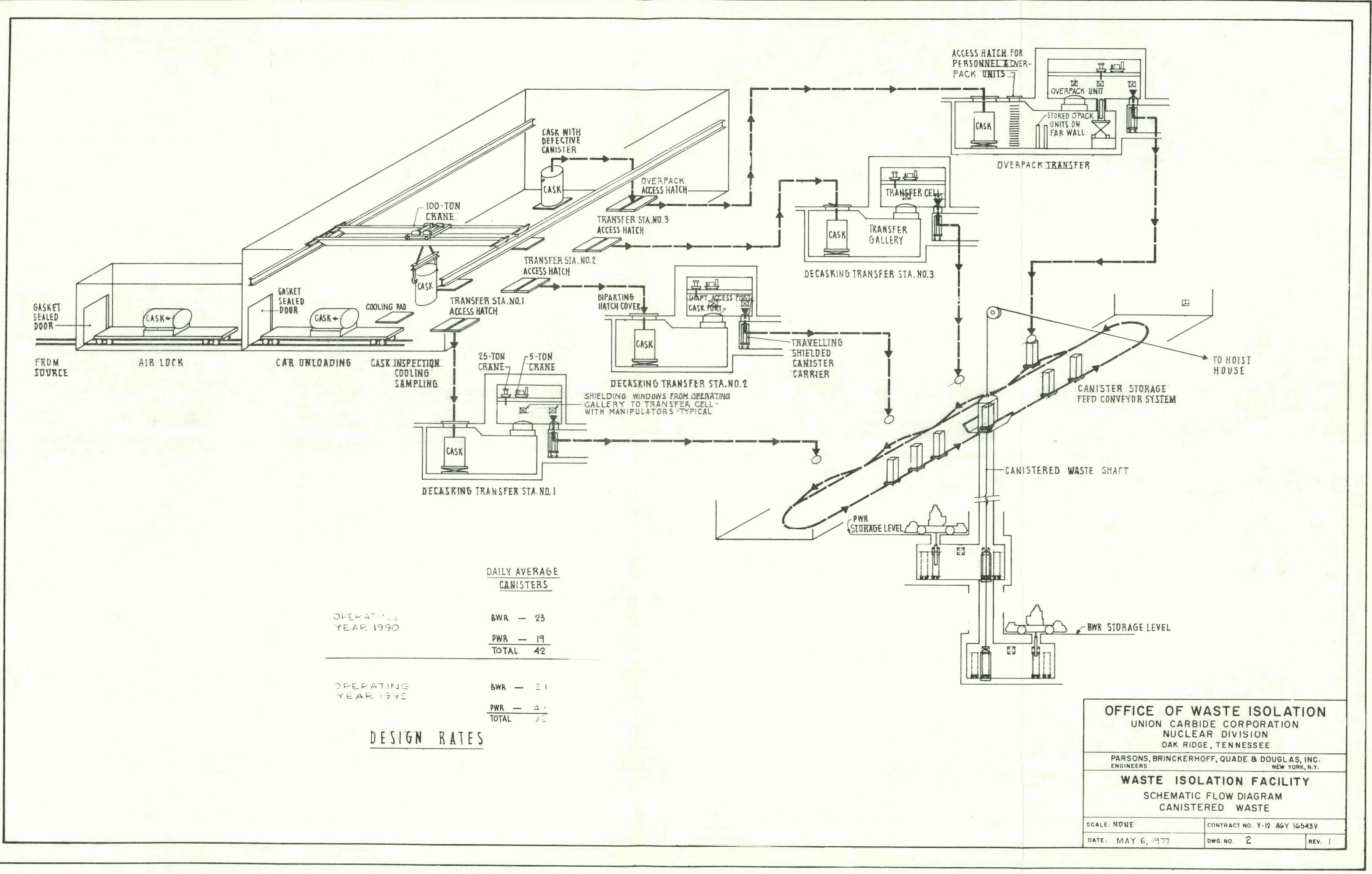




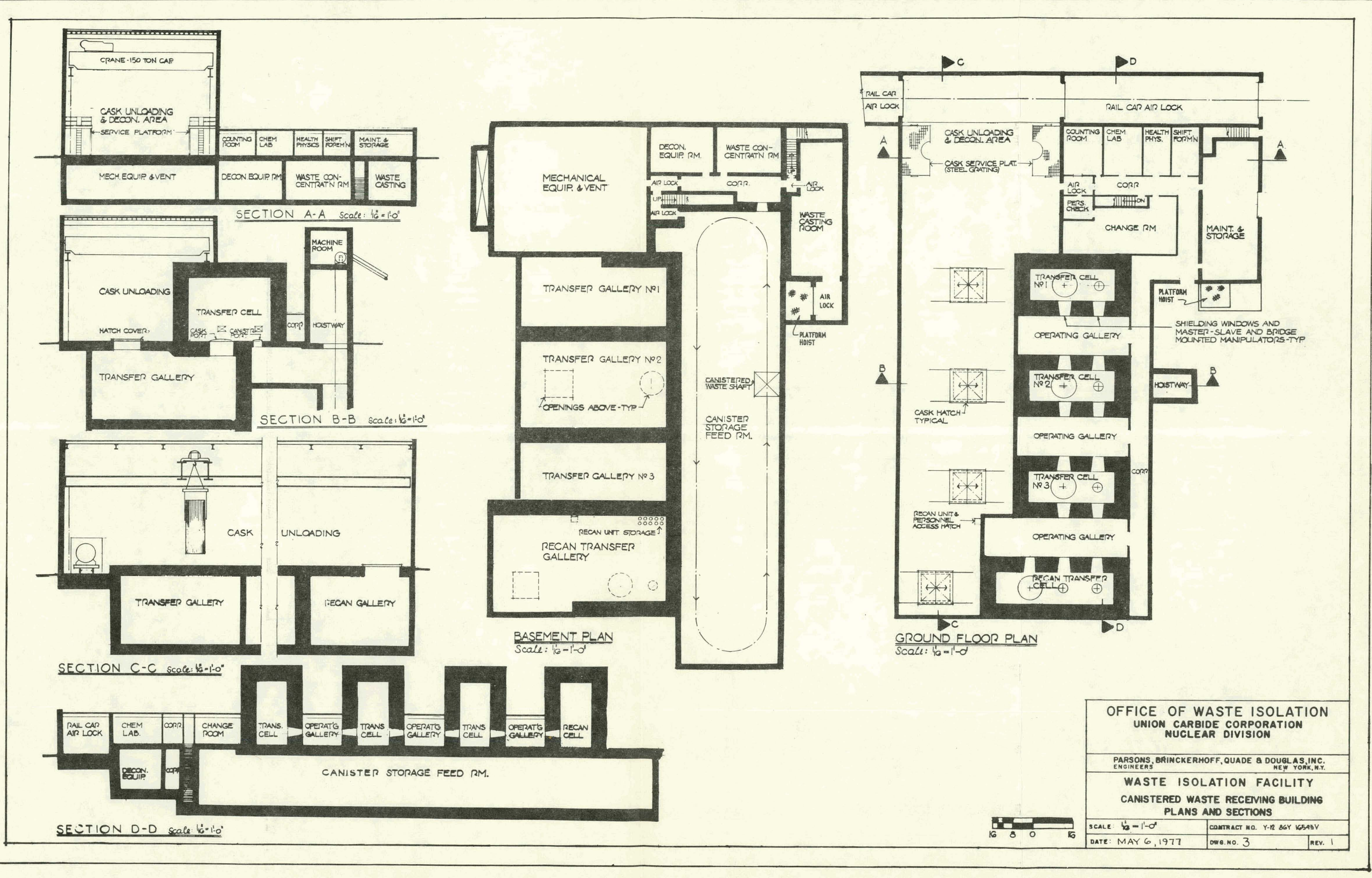




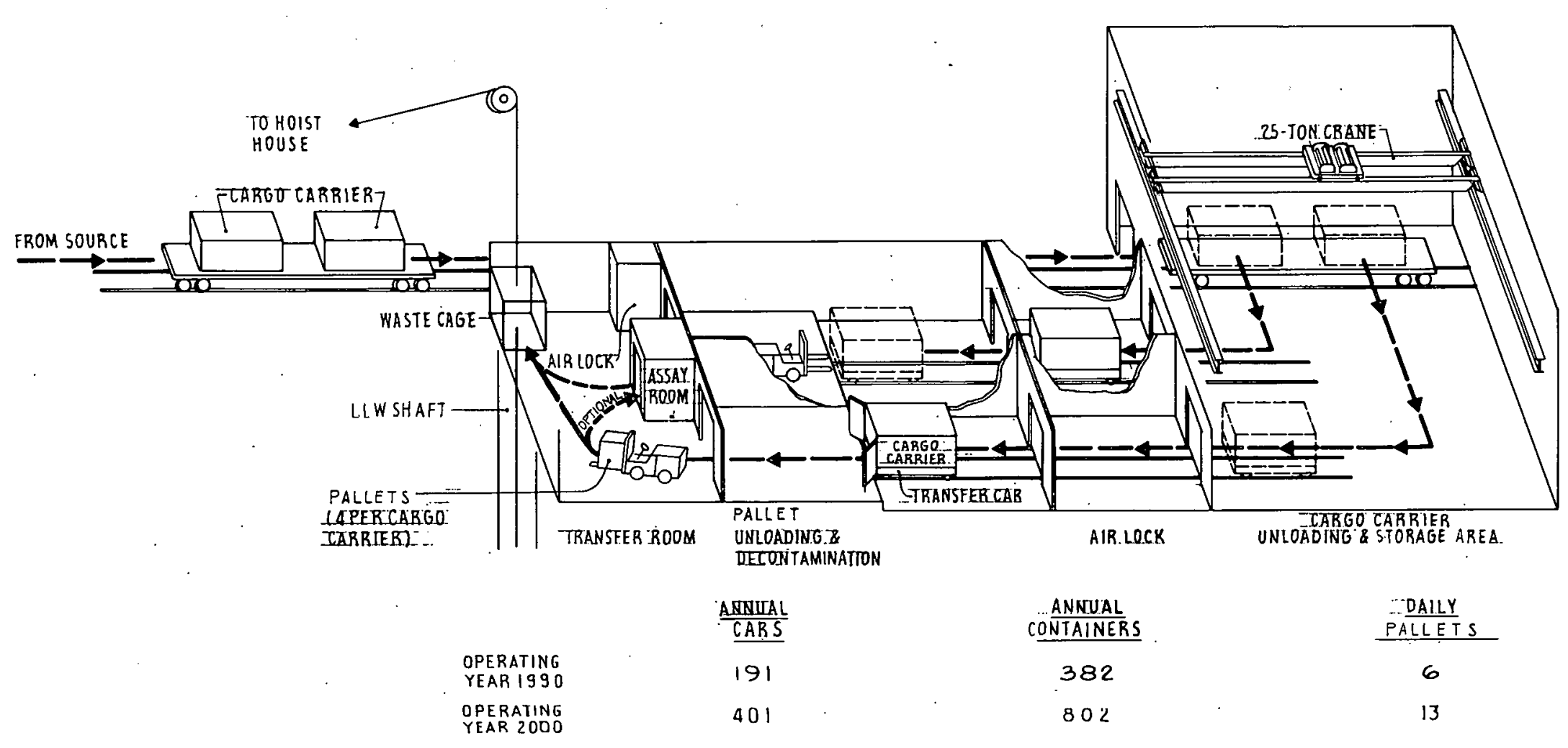

DESIGN RATES

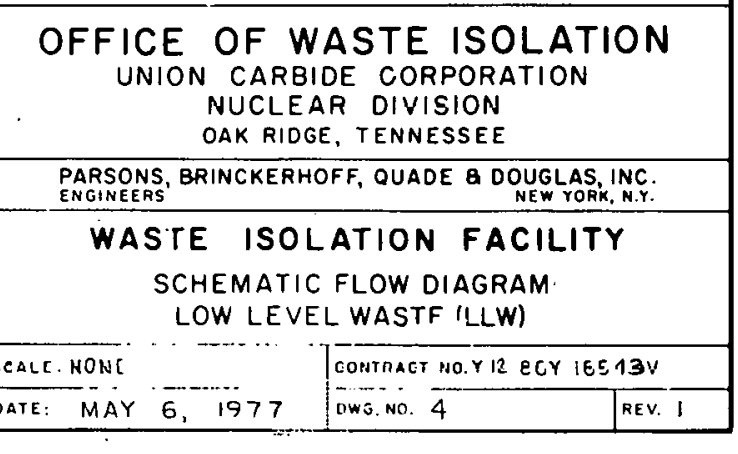




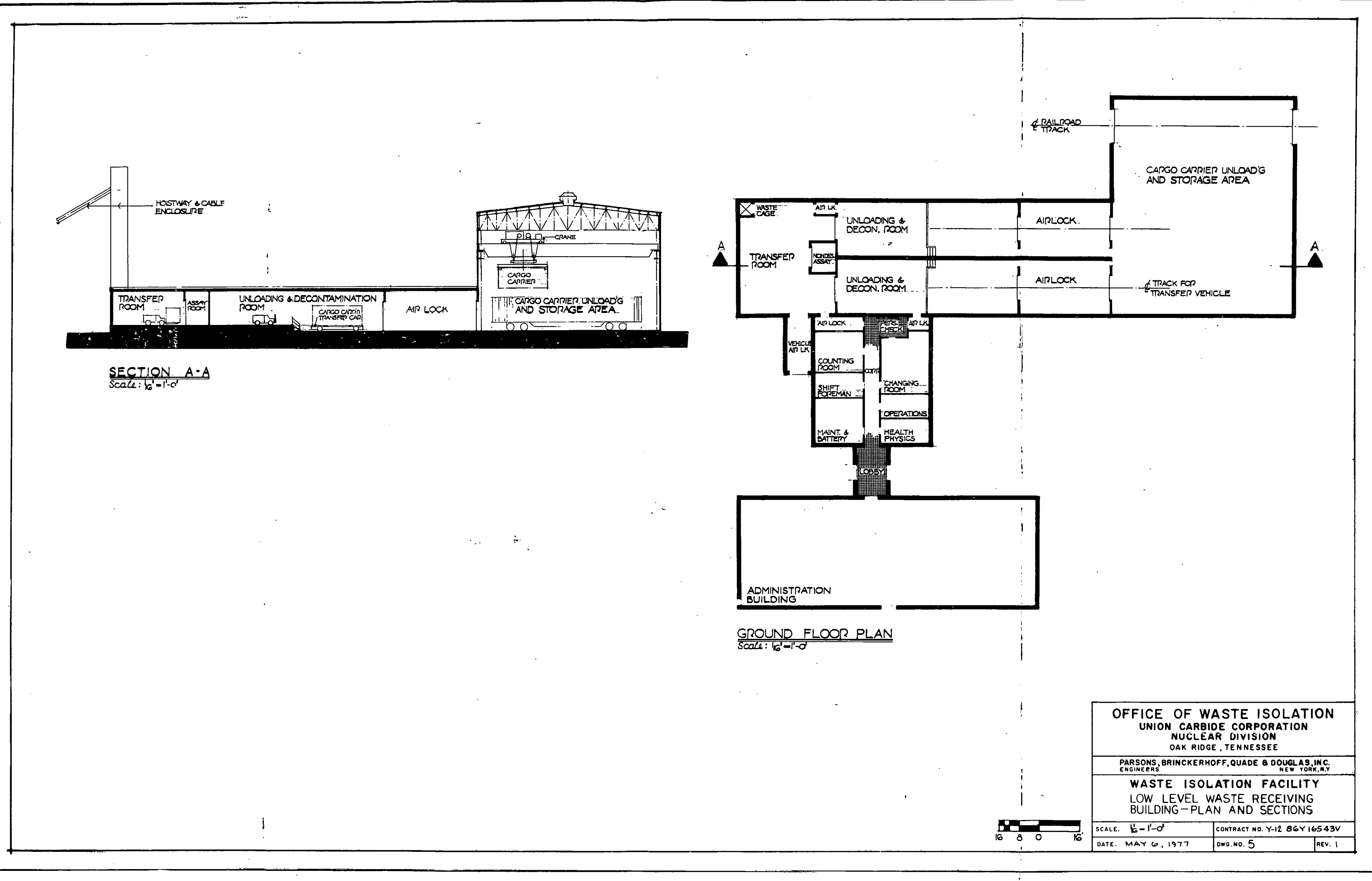




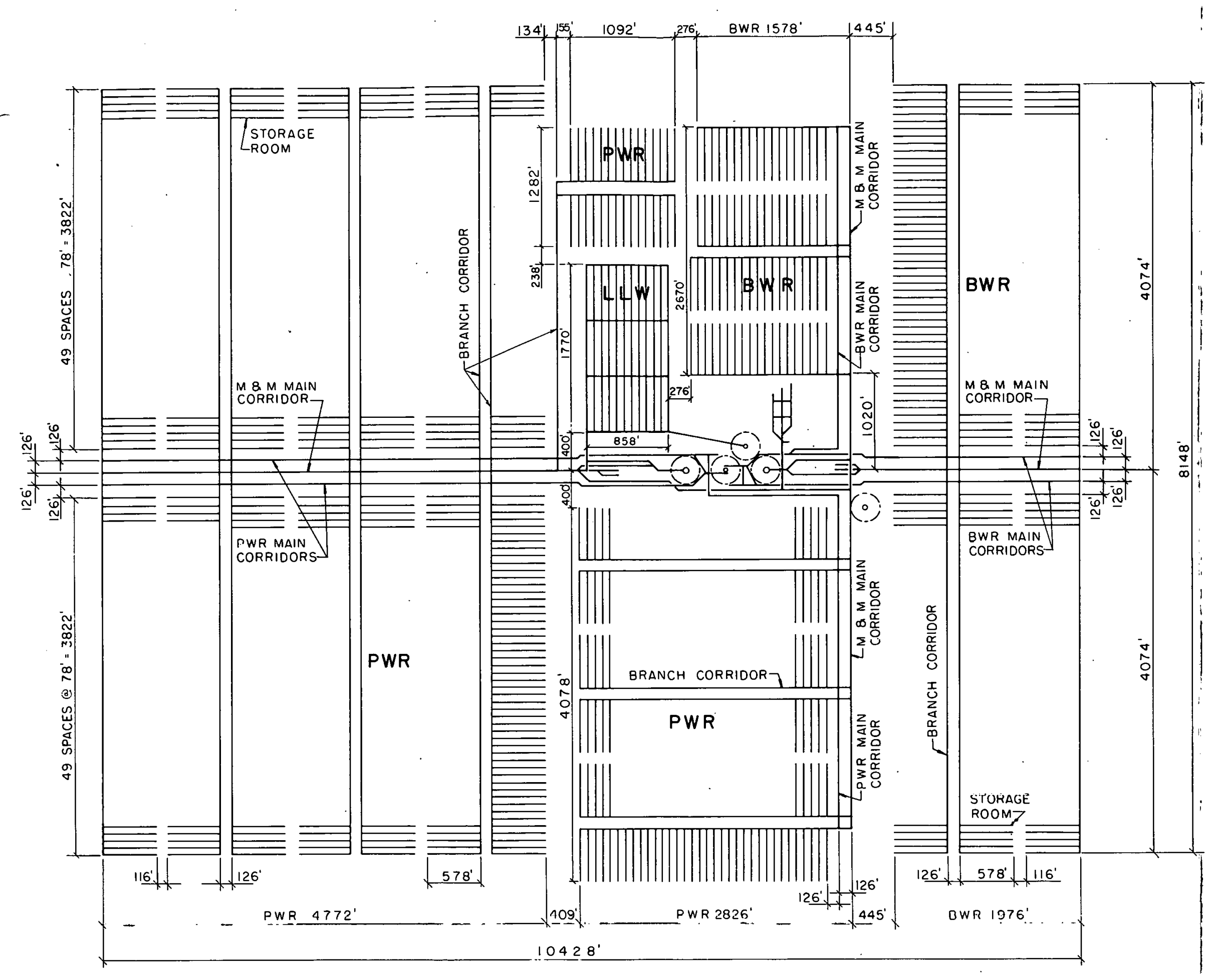

MINE MASTER PLAN

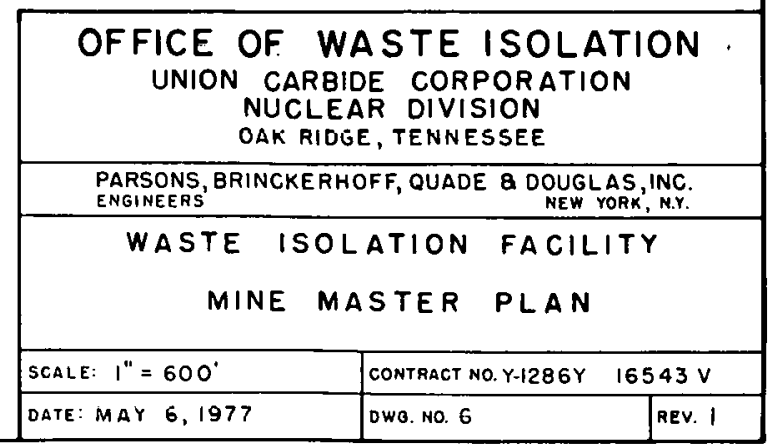




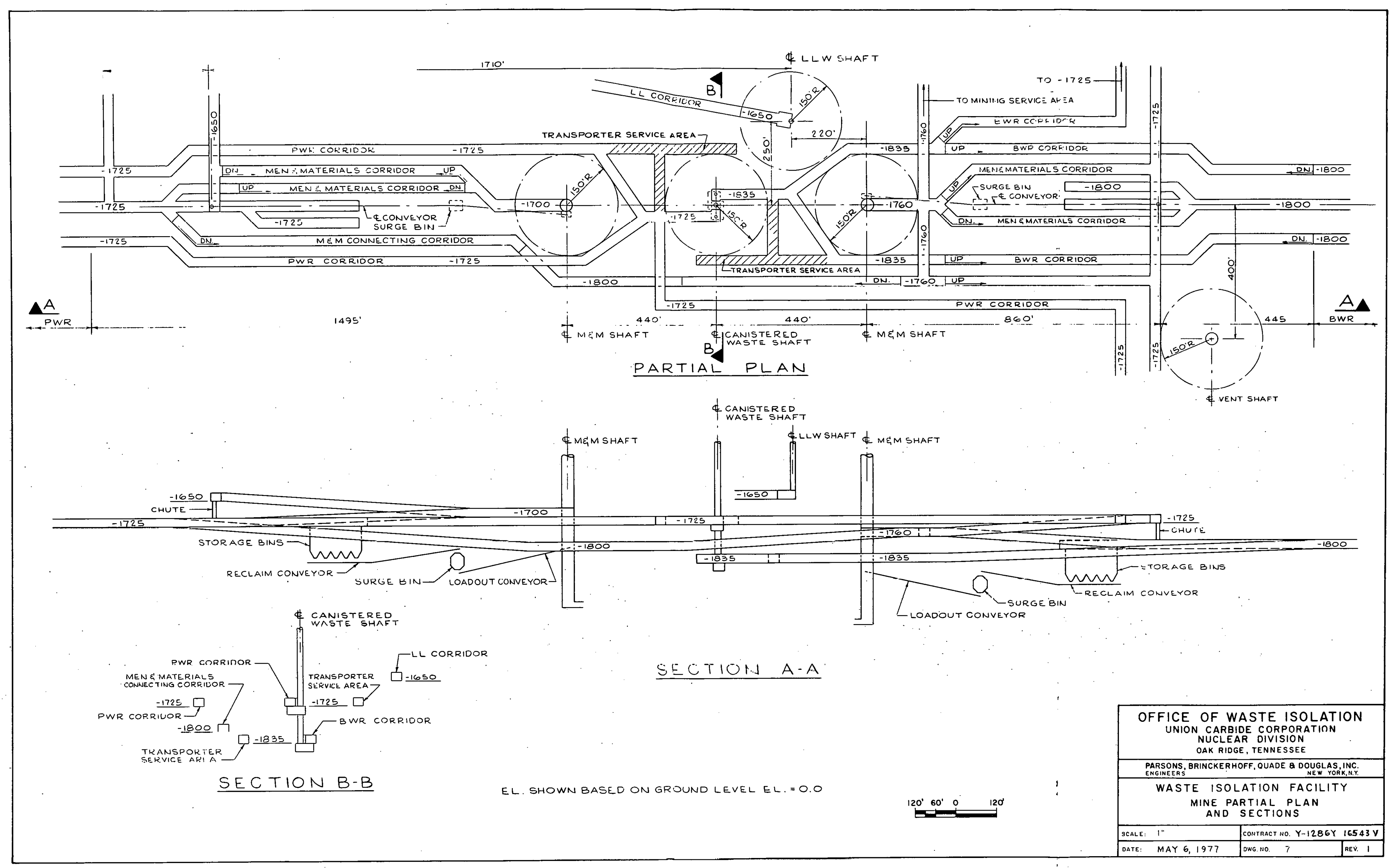




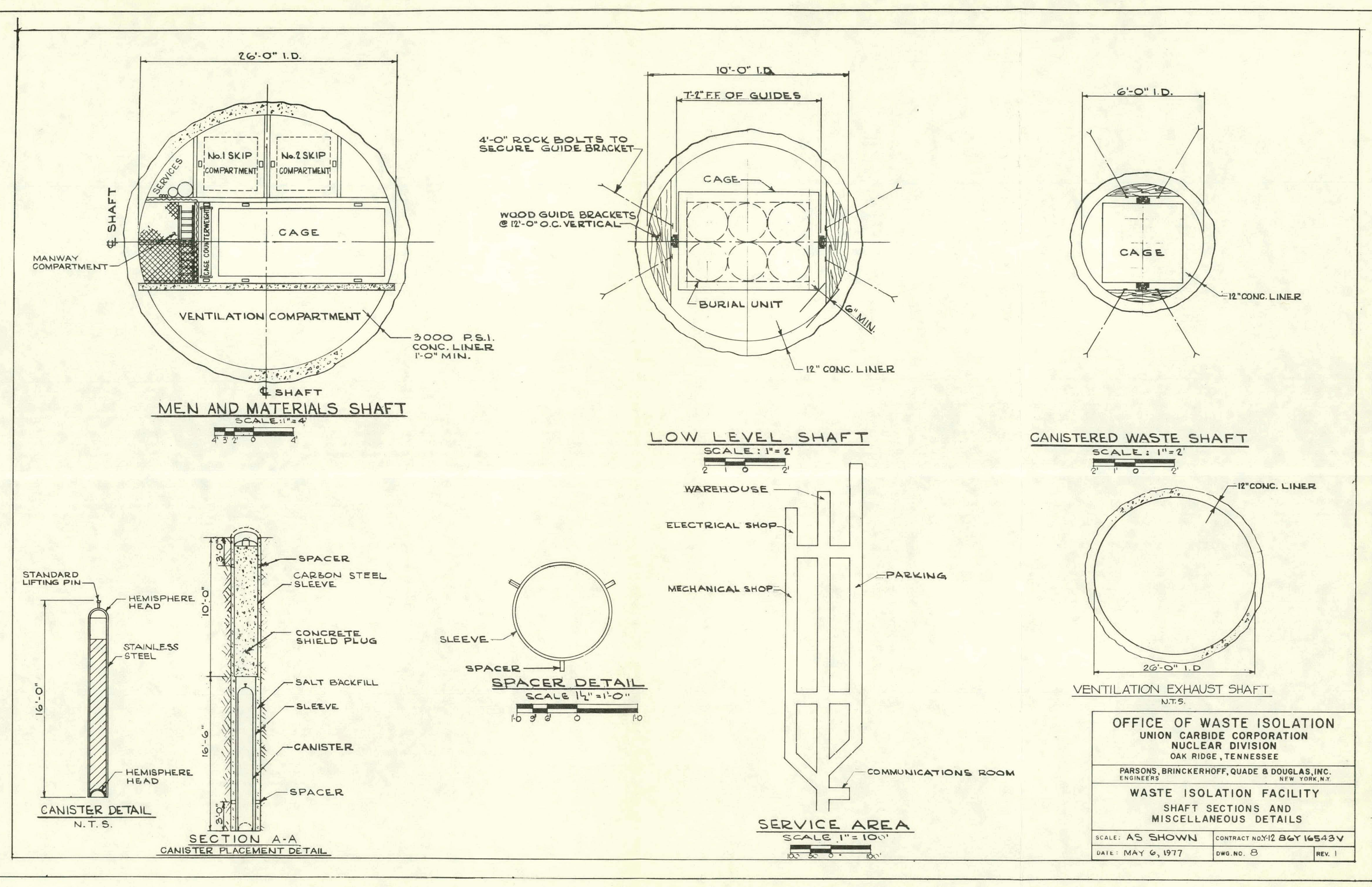



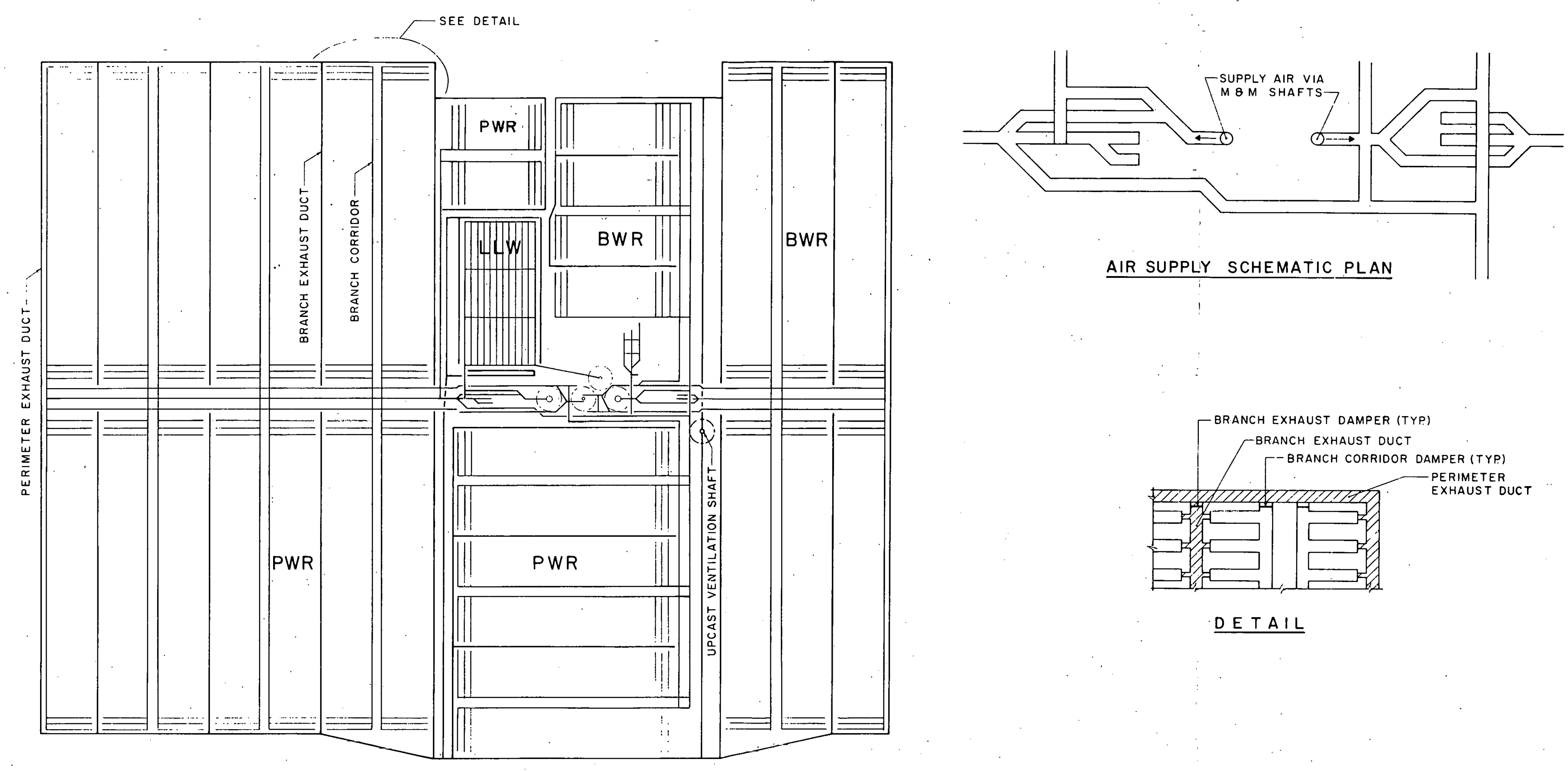

VENTILATION PLAN

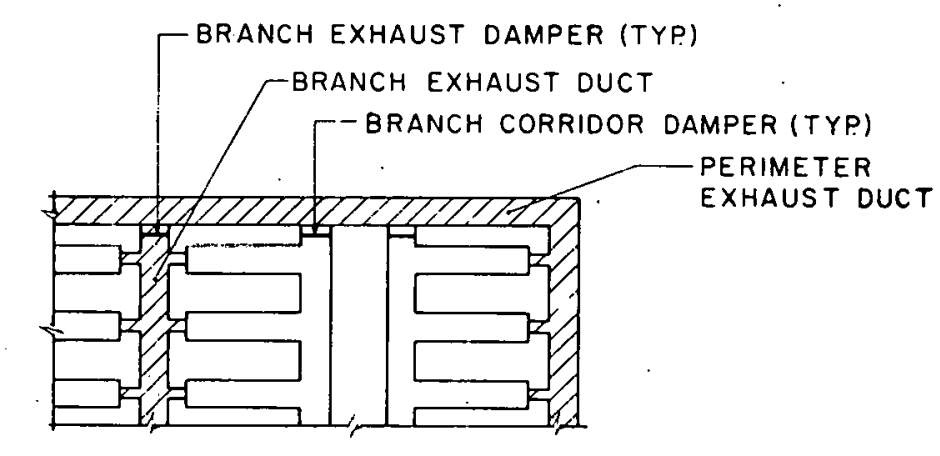

DETAIL

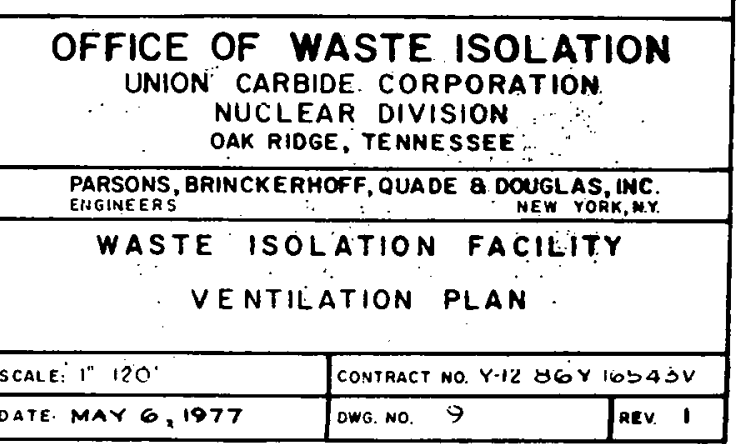



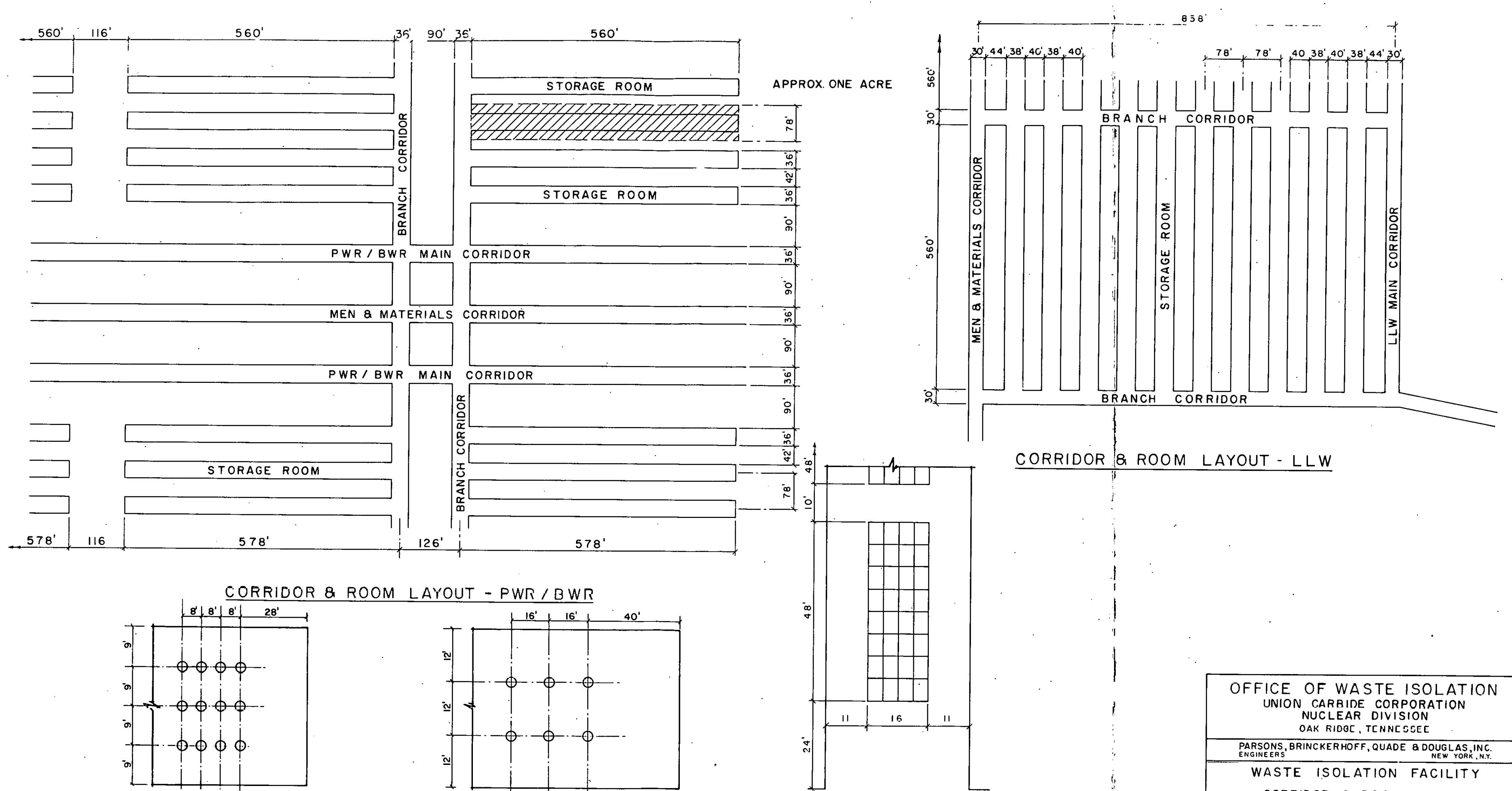

CORRIDOR \& ROOM LAYOUT - LLW

CORRIDOR \& ROOM LAYOUT - PWR / BWR
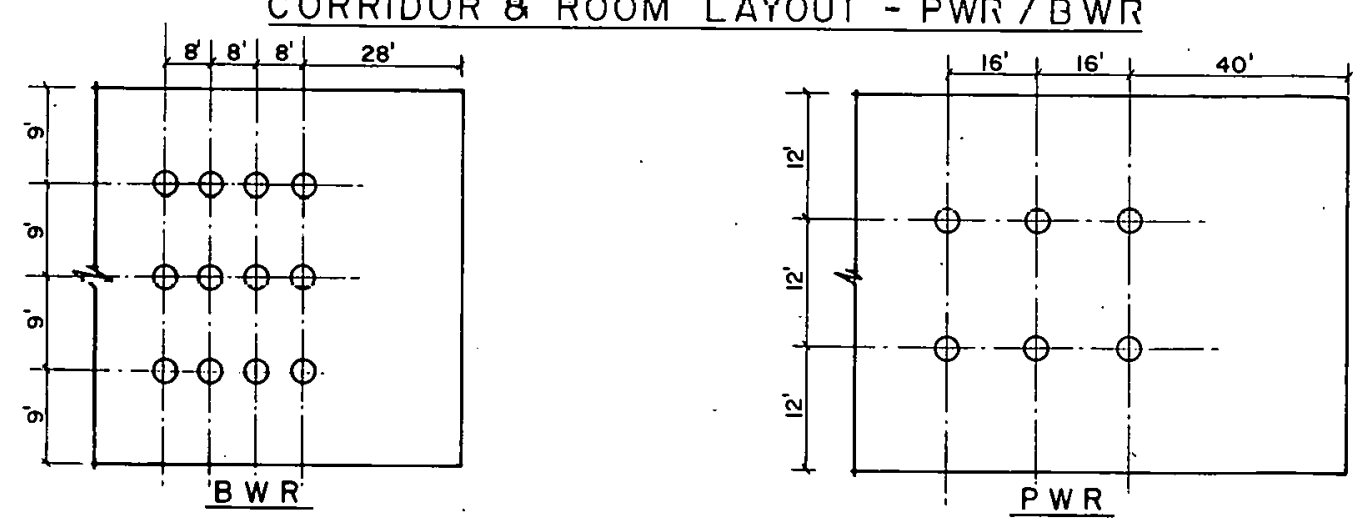

STORAGE ROOM PLAN

$L L W$

STORAGE ROOM LAYOUT 